\title{
WTO rules on technical barriers to trade
}

Citation for published version (APA):

Van den Bossche, P., Prevost, D., \& Matthee, M. (2005). WTO rules on technical barriers to trade. (1 ed.) (pp. 82). Universiteit Maastricht. Maastricht Faculty of Law Working Papers Vol. 2005 No. 6 https://doi.org/10.2139/SSRN.978167

Document status and date:

Published: 01/01/2005

DOI:

10.2139/SSRN.978167

Document Version:

Publisher's PDF, also known as Version of record

\section{Please check the document version of this publication:}

- A submitted manuscript is the version of the article upon submission and before peer-review. There can be important differences between the submitted version and the official published version of record.

People interested in the research are advised to contact the author for the final version of the publication, or visit the DOI to the publisher's website.

- The final author version and the galley proof are versions of the publication after peer review.

- The final published version features the final layout of the paper including the volume, issue and page numbers.

Link to publication

\footnotetext{
General rights rights.

- You may freely distribute the URL identifying the publication in the public portal. please follow below link for the End User Agreement:

www.umlib.nl/taverne-license

Take down policy

If you believe that this document breaches copyright please contact us at:

repository@maastrichtuniversity.nl

providing details and we will investigate your claim.
}

Copyright and moral rights for the publications made accessible in the public portal are retained by the authors and/or other copyright owners and it is a condition of accessing publications that users recognise and abide by the legal requirements associated with these

- Users may download and print one copy of any publication from the public portal for the purpose of private study or research.

- You may not further distribute the material or use it for any profit-making activity or commercial gain

If the publication is distributed under the terms of Article $25 \mathrm{fa}$ of the Dutch Copyright Act, indicated by the "Taverne" license above, 


\section{Maastricht Working Papers \\ Faculty of Law}

WTO Rules on Technical Barriers to Trade

Peter Van den Bossche, Denise Prévost

\& Mariëlle Matthee

2005-6 


\section{All rights reserved.}

No part of this paper may be reproduced in any form without the permission of the author(s).

This Working Paper series from the Faculty of Law, University of Maastricht, aims to further excellence in scholarship. It allows Maastricht-based authors to bring their work-in-progress

to a wide audience, facilitating fruitful discussion and critical input on nascent ideas and projects to the benefit of both author and reader. To this end, readers are encouraged to treat the series as interactive and to contact authors with their comments.

Those wishing to submit papers for consideration are invited to send work to working.papers@law.unimaas.nl.

Our submission guidelines and further information are available at http://www.unimaas.nl/maastrichtworkingpapers

(C) Peter Van den Bossche, Denise Prévost and Mariëlle Matthee Published in Maastricht, October 2005

Faculty of Law

Universiteit Maastricht

Postbox 616

$6200 \mathrm{MD}$

Maastricht

The Netherlands

Author emails: p.vandenbossche@ir.unimaas.nl, d.prevost@ir.unimaas.nl \& m.matthee@asser.nl

This paper is to be cited as Maastricht Faculty of Law Working Paper 2005/6 


\title{
WTO Rules on Technical Barriers to Trade
}

\author{
Peter Van den Bossche, \\ Denise Prévost and Mariëlle Matthee ${ }^{1}$
}

\section{TABLE OF CONTENTS}

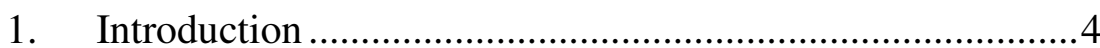

2. The TBT Agreement .................................................................5

2.1. Scope of Application of the TBT Agreement ...................5

2.2. Relationship with Other WTO Agreements ................... 13

2.3. Basic Substantive Provisions of the TBT Agreement .....14

2.4. Other Substantive Provisions ..........................................21

2.5. Institutional and Procedural Provisions...........................24

2.6. Special Provisions for Developing Countries ................26

3. The SPS Agreement ...........................................................2 27

3.1. Scope of Application of the SPS Agreement ..................28

3.2. Relationship with Other WTO Agreements ...................31

3.3. Basic Principles of the SPS Agreement .........................33

3.4. Risk Analysis Obligations ..........................................44

3.5. Other Substantive Provisions .........................................62

3.6. Institutional and Procedural Provisions..........................69

3.7. Special Provisions for Developing Countries .................75

4. Summary …............................................................. 77

\section{ABSTRACT}

In modern society, products are often subject to requirements relating to their characteristics and/or the manner in which they are produced. The purpose of these requirements may be the protection of life or health, the protection of the environment, the prevention of deceptive practices or to ensure the quality of products. These requirements may constitute formidable barriers to trade. Moreover, procedures set up to verify whether a product meets certain requirements may obstruct trade. These barriers to trade are referred to as technical barriers to trade. One must distinguish between:

- the general category of technical barriers to trade, for which rules have been set out in the TBT Agreement; and

- a special category of technical barriers to trade, namely sanitary and phytosanitary measures, for which rules are provided in the SPS Agreement.

The rules of the TBT Agreement and the SPS Agreement are of great importance to international trade. They go significantly beyond the GATT obligations not to discriminate

Peter Van den Bossche is Professor of International Economic Law and Head of the International and European Law Department at the Faculty of Law of Maastricht University. From 1997 to 2001, he was Counsellor to the Appellate Body of the WTO. In 2001 he served as Acting Director of the Appellate Body Secretariat. Denise Prévost is a lecturer in international economic law at the Faculty of Law of Utrecht University, Mariëlle Matthee is a doctoral researcher at the Faculty of Law of Maastricht University. The authors wish to thank Maikel Beckers and Jill Roche for their able assistance in preparing this working paper for publication. 
among or against imported products or not to impose quantitative restrictions but also impose certain international disciplines on national regulation regarding products, their characteristics and production. This working paper gives an overview of the scope of application as well as the substantive and institutional/procedural provisions of the $T B T$ Agreement and the SPS Agreement.

Keywords: WTO law, Market Access, Technical Barriers to Trade, TBT Agreement, SPS Agreement.

\section{INTRODUCTION}

TV sets, toys, cosmetics, medical equipment, fertilisers, meat and cheese are all subject to requirements relating to their characteristics and/or the manner in which they are produced. The purpose of these requirements may be the protection of life or health, the protection of the environment, the prevention of deceptive practices or to ensure the quality of products. These requirements may be mandatory, set and enforced by governments. More often, however, these requirements are rules laid down by national standardisation bodies, which are not mandatory but are nevertheless generally adopted in business transactions in a given country. In both cases, these requirements may constitute formidable barriers to trade. TV sets and cheese made according to the requirements of country A may be banned from, or difficult to market in, country B when the requirements of country B relating to the characteristics or the manner of production are different. Furthermore, procedures used to verify whether a product meets certain mandatory or voluntary requirements may obstruct trade.

Measures of this kind are commonly referred to as 'technical barriers to trade'. This paper deals with the WTO law on such barriers. One must distinguish between:

- the general category of technical barriers to trade, for which rules have been set out in the Agreement on Technical Barriers to Trade, commonly referred to as the TBT Agreement; and

- a special category of technical barriers to trade, namely sanitary and phytosanitary measures, for which rules are provided in the Agreement on the Application of Sanitary and Phytosanitary Measures, commonly referred to as the SPS Agreement.

The rules of the TBT Agreement and the SPS Agreement are of great importance to international trade. As discussed below, these rules go significantly beyond the GATT obligations not to discriminate among or against imported products. They impose certain 
international disciplines on national regulation regarding products, their characteristics and production.

\section{THE TBT AGREEMENT}

As noted above, the WTO rules on the general category of technical barriers to trade are set out in the TBT Agreement. This section discusses:

- the scope of application of the TBT Agreement;

- the relationship between the TBT Agreement and other WTO agreements, in particular, the SPS Agreement and the GATT 1994;

- the substantive provisions of the TBT Agreement

- the institutional and procedural provisions of the TBT Agreement; and

- $\quad$ special provisions for developing country Members.

\subsection{Scope of Application of the TBT Agreement}

With respect to the scope of application of the TBT Agreement, this section distinguishes between the substantive scope of application, i.e., the types of measures to which the agreement applies, the personal scope of application, i.e., the entities to whom rules of the TBT Agreement apply, and the temporal scope of application of the agreement.

\subsubsection{Substantive scope of application}

The rules of the TBT Agreement apply to:

- technical regulations;

- standards; and

- conformity assessment procedures.

As the Appellate Body stated in EC - Asbestos, the TBT Agreement thus applies to a 'limited class of measures'. ${ }^{2}$ The three types of measures to which the TBT Agreement applies, are defined in Annex 1 of the TBT Agreement.

In Annex 1.1, a technical regulation is defined as:

2 Appellate Body Report, EC - Asbestos, para. 80. 
... [a] document which lays down product characteristics or their related processes and production methods, including the applicable administrative provisions, with which compliance is mandatory. It may also include or deal exclusively with terminology, symbols, packaging, marking or labelling requirements as they apply to a product, process or production method.

For example, a law requiring that batteries of 9 Volts or more be rechargeable, or a law requiring that wine be sold in green glass bottles are technical regulations within the meaning of the TBT Agreement. A law requiring that the production of pharmaceutical products meet certain requirements regarding manufacturing practices and plant cleanliness is also a technical regulation falling within the scope of application of the TBT Agreement.

Annex 1.2 of the TBT Agreement defines a standard as:

... [a] document approved by a recognised body, that provides, for common and repeated use, rules, guidelines or characteristics for products or related processes and production methods, with which compliance is not mandatory. It may also include or deal exclusively with terminology, symbols, packaging, marking or labelling requirements as they apply to a product, process or production method.

Contrary to technical regulations, standards are of a voluntary nature, meaning compliance is not mandatory.

The voluntary standards set by CENELEC (the European Committee for Electrotechnical Standardisation), such as standards for mobile phones or handheld computers, are clearly standards within the meaning of the TBT Agreement.

In addition to technical regulations and standards, conformity assessment procedures also fall within the scope of application of the TBT Agreement. Conformity assessment procedures are defined in Annex 1.3 of the TBT Agreement as:

... any procedure used, directly or indirectly, to determine that relevant requirements in technical regulations or standards are fulfilled.

Examples of conformity assessment procedures include, for example, procedures for sampling, testing and inspection.

The TBT Agreement applies to technical regulations, standards and conformity assessment procedures relating to:

- products (both industrial and agricultural); and 


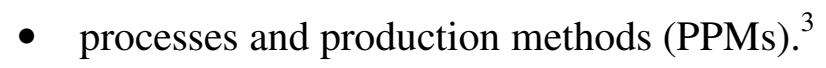

It is a subject of much debate, however, whether the processes and production methods, to which the TBT Agreement applies, include the so-called non-product related processes and production methods (NPR-PPMs). This term refers to processes and production methods that do not affect the characteristics of the final product put on the market. An example of a technical regulation concerning a NPR-PPM is the prohibition of the use of environmentally unfriendly sources of energy in the production of a product. Another example is the prohibition to market beef from cattle fed with genetically modified fodder. During the negotiations on the TBT Agreement, discussion took place on whether this group should be included in the scope of the agreement. This discussion, however, did not result in consensus. ${ }^{4}$ The definitions in Annex 1, paragraphs 1 to 3 , seem to indicate that technical regulations, standards and conformity assessment procedures relating to NPR-PPMs do not fall with the scope of application of the TBT Agreement. ${ }^{5}$

In two disputes to date, EC - Asbestos and EC - Sardines, panels and the Appellate Body had occasion to examine whether the measures at issue were technical regulations falling within the scope of the TBT Agreement. In EC-Asbestos, the measure at issue consisted of, on one hand, a general ban on asbestos and asbestos-containing products and, on the other hand, limited exceptions referring to situations in which asbestos-containing products would be allowed. The Panel concluded that the ban itself was not a technical regulation, whereas the exceptions to the ban were. ${ }^{6}$ On appeal, the Appellate Body reversed the Panel's finding that the ban did not constitute a technical regulation. In addressing this issue, the Appellate Body first firmly rejected the Panel's approach of considering separately the ban and the exceptions to the ban. According to the Appellate Body, the 'proper legal character' of the measure cannot be determined unless the measure is looked at as a whole. The Appellate Body stated:

Article 1 of the Decree contains broad, general prohibitions on asbestos and products containing asbestos. However, the scope and generality of those prohibitions can only be understood in light of the exceptions to it which, albeit for a limited period, permit, inter alia, the use of certain products containing asbestos and,

3 Article 1.3 and the explanatory note to Annex 1, paragraph 2, of the TBT Agreement. Note that the TBT Agreement does not apply to technical regulations, standards and conformity assessment procedures that deal with services.

4 Committee on Technical Barriers to Trade, 'Negotiating History of the Coverage of the Agreement on Technical Barriers to Trade with regard to Labelling Requirements, Voluntary Standards and Processes and Production Methods Unrelated to Product Characteristics', Note by the Secretariat, G/TBT/W11, dated 29 August 1995.

5 Note that the definitions in Annex 1.1 and Annex 1.2 state: '...products and related processes and production methods'. [Emphasis added]

6 Panel Report, EC - Asbestos, paras. 8.63 and 8.70 
principally, products containing chrysotile asbestos fibres. The measure is, therefore, not a total prohibition on asbestos fibres, because it also includes provisions that permit, for a limited duration, the use of asbestos in certain situations. Thus, to characterize the measure simply as a general prohibition, and to examine it as such, overlooks the complexities of the measure, which include both prohibitive and permissive elements. ${ }^{7}$

The Appellate Body thus concluded that the measure at issue was to be examined as an integrated whole, taking into account as appropriate the prohibitive and the permissive elements that are part of it. ${ }^{8}$

The Appellate Body then examined whether the measure at issue, considered as a whole, was a technical regulation within the meaning of the TBT Agreement. On the basis of the definition of a 'technical regulation' of Annex 1.1, quoted above, the Appellate Body set out a number of considerations for determining whether a measure is a technical regulation. This section discusses these considerations.

First, for a measure to be a 'technical regulation', it must 'lay down' - i.e., set forth, stipulate, or provide - 'product characteristics'. With respect to the term 'characteristics', the Appellate Body noted:

... the "characteristics" of a product include, in our view, any objectively definable "features", "qualities", "attributes", or other "distinguishing mark" of a product. Such "characteristics" might relate, inter alia, to a product's composition, size, shape, colour, texture, hardness, tensile strength, flammability, conductivity, density, or viscosity. In the definition of a "technical regulation" in Annex 1.1, the TBT Agreement itself gives certain examples of "product characteristics" - "terminology, symbols, packaging, marking or labelling requirements". These examples indicate that "product characteristics" include, not only features and qualities intrinsic to the product itself, but also related "characteristics", such as the means of identification, the presentation and the appearance of a product. ${ }^{9}$

The Appellate Body also noted that a technical regulation may be confined to laying down only one or a few product characteristics.

Second, a 'technical regulation' must regulate the characteristics of products in a binding or compulsory fashion. According to the Appellate Body, it follows that:

\footnotetext{
Appellate Body Report, EC - Asbestos, para. 64.

Ibid.

$9 \quad$ Ibid., para. 67.
} 
... with respect to products, a "technical regulation" has the effect of prescribing or imposing one or more “characteristics" - "features", “qualities”, “attributes”, or other "distinguishing mark". 10

Product characteristics may be prescribed or imposed with respect to products in either a positive or a negative form. That is, the document may provide, positively, that products must possess certain 'characteristics', or the document may require, negatively, that products must not possess certain 'characteristics'. In both cases, the legal result is the same: the document 'lays down' certain binding 'characteristics' for products. ${ }^{11}$

Third, a 'technical regulation' must be applicable to an identifiable product, or group of products. Otherwise, enforcement of the regulation will be, in practical terms, impossible. Clearly, compliance with this obligation requires identification of the product coverage of a technical regulation. The Panel in EC - Asbestos interpreted this to mean that a 'technical regulation' must apply to 'given' products which are actually named, identified or specified in the regulation. The Appellate Body disagreed. Nothing in the text of the TBT Agreement suggests that the products concerned need be named or otherwise expressly identified in a 'technical regulation'. The Appellate Body noted that:

... there may be perfectly sound administrative reasons for formulating a "technical regulation" in a way that does not expressly identify products by name, but simply makes them identifiable - for instance, through the "characteristic" that is the subject of regulation. ${ }^{12}$

On the basis of the above three considerations, the Appellate Body examined the measure at issue in EC - Asbestos, a French Decree, noting that the first and second paragraphs of Article 1 of the Decree imposed a prohibition on asbestos fibres. According to the Appellate Body, prohibition on these fibres does not, in itself , prescribe or impose any 'characteristics' on asbestos fibres but simply bans them in their natural state. Accordingly, if this measure consisted only of a prohibition on asbestos fibres, it might not constitute a 'technical regulation'. The Appellate Body then noted, however:

An integral and essential aspect of the measure is the regulation of "products containing asbestos fibres", which are also prohibited by Article 1, paragraphs I and II of the Decree. It is important to note here that, although formulated negatively - products containing asbestos are prohibited - the measure, in this respect, effectively prescribes or imposes certain objective features, qualities or "characteristics" on all products. That is, in effect, the measure provides that all products must not contain asbestos fibres. Although this prohibition against

$10 \quad$ Ibid., para. 68.

11 Ibid., para. 69.

12 Ibid., para. 70 
products containing asbestos applies to a large number of products, and although it is, indeed, true that the products to which this prohibition applies cannot be determined from the terms of the measure itself, it seems to us that the products covered by the measure are identifiable: all products must be asbestos free; any products containing asbestos are prohibited. We also observe that compliance with the prohibition against products containing asbestos is mandatory and is, indeed, enforceable through criminal sanctions. ${ }^{13}$

The prohibition of all asbestos-containing products is a measure which effectively prescribes - although negatively - certain objective characteristics for all products.

Furthermore, the Appellate Body noted that Articles 2, 3 and 4 of the Decree contain certain exceptions to the prohibitions found in Article 1 of the Decree. Any person seeking to avail of these limited exceptions must provide a detailed justification to the authorities, complete with necessary supporting documentation concerning 'the state of scientific and technological progress'. Compliance with these administrative requirements is mandatory. Through the exceptions to the prohibitions, the measure at issue sets out the applicable administrative provisions, with which compliance is mandatory' for products with certain objective 'characteristics'.

The Appellate Body thus concluded in EC - Asbestos:

Viewing the measure as an integrated whole, we see that it lays down "characteristics" for all products that might contain asbestos, and we see also that it lays down the "applicable administrative provisions" for certain products containing chrysotile asbestos fibres which are excluded from the prohibitions in the measure. Accordingly, we find that the measure is a "document" which "lays down product characteristics ... including the applicable administrative provisions, with which compliance is mandatory." For these reasons, we conclude that the measure constitutes a "technical regulation" under the TBT Agreement. ${ }^{14}$

Confirming its ruling in EC - Asbestos, the Appellate Body in EC - Sardines established a three-tier test for determining whether a measure is a 'technical regulation' under the TBT Agreement:

- the measure must apply to an identifiable product or group of products;

- the measure must lay down product characteristics; and

- compliance with the product characteristics laid down in the measure must be mandatory.

\footnotetext{
13 Ibid., para. 72 .

14 Ibid., para. 75.
} 
Applying this test in EC - Sardines to EC Regulation 2136/89 on common marketing standards for preserved sardines, the Appellate Body further clarified its reasoning in EC Asbestos. With regard to the first element of its three-tier test, the Appellate Body held that a measure which did not expressly identify the products to which it applied could still be applicable to identifiable products (as required by the first element of the test). The tool that the Appellate Body used to determine whether, in this case, Sardinops sagax was an identifiable product was by examining the way the EC Regulation was enforced. As the enforcement of the EC Regulation had led to a prohibition against labelling Sardinops sagax as 'preserved sardines', this product was therefore considered to be identifiable. ${ }^{15}$

With regard to the second element of the three-tier test, the question arose whether a 'naming' rule, such as the rule to name Sardina pilchardus 'preserved sardines' laid down product characteristics. The Appellate Body held in this respect that product characteristics include means of identification and that, therefore, the naming rule at issue definitely met the requirement of the second element of the test. ${ }^{16}$

\subsubsection{Personal scope of application}

Although the TBT Agreement is mainly addressed to central government bodies, it explicitly aims to extend its application to 'other bodies' responsible for the establishment of technical regulations, standards, or execution of conformity assessment procedures. These 'other bodies' covered by the TBT Agreement primarily consist of local government bodies and non-governmental bodies.

Local government bodies are all bodies of government other than the central government, such as provinces, Länder, cantons or municipalities. They include any organ subject to the 'control of such a [local] government in respect of the activity in question'. ${ }^{17}$ Nongovernmental bodies in the context of the TBT Agreement are defined as bodies other than central government or local government bodies that ha[ve] legal power to enforce a technical regulation'. ${ }^{18}$

The TBT Agreement extends its application to those 'other bodies' by imposing, on WTO Members, the obligation:

\footnotetext{
15 Appellate Body Report, EC - Sardines, para 184.

16 Ibid., paras. 190-191.

17 Annex 1.7 of the TBT Agreement.

18 Annex 1.8 of the TBT Agreement.
} 
- to take measures in order to ensure compliance with the TBT Agreement by local government bodies and non-governmental bodies; or

- to refrain from taking measures that could encourage actions by these other bodies that are inconsistent with the provisions of the TBT Agreement.

It does so with respect to the obligations related to technical regulations, standards and procedures for assessment of conformity. ${ }^{19}$ Note, in particular the 'Code of Good Practice' in Annex 3 of the TBT Agreement. This 'Code of Good Practice' applies to the preparation, adoption and use of standards. Members have to ensure that their central government standardising bodies accept and comply with the 'Code of Good Practice'. In addition, Members have, pursuant to Article 4 of the TBT Agreement, the obligation to take reasonable measures as are available to them to ensure that local and non-governmental standardising bodies also accept and comply with the Code. ${ }^{20}$

\subsubsection{Temporal scope of application}

In EC - Sardines, the issue arose whether the TBT Agreement applied to technical regulations which were already in force on 1 January 1995, i.e., the date on which the TBT Agreement entered into force. In deciding this issue, the Panel and Appellate Body referred to Article 28 of the Vienna Convention on the Law of Treaties which states:

... unless a different intention appears from the treaty or is otherwise established, its provisions do not bind a party in relation to any act or fact which took place or any situation which ceased to exist before the date of entry into force of the treaty with respect to that party.

Applying this basic provision of treaty law, both the Panel and the Appellate Body held that the EC Regulation, although adopted prior to 1 January 1995, was still in force and thus could not be considered as a situation which has ceased to exist. ${ }^{21}$ Therefore, it can be concluded that the TBT Agreement applies to technical regulations which, although adopted prior to 1995 , are still in force.

19 See Articles 3, 4, 7 and 8 of the TBT Agreement.

20 As of 18 November 2002, 145 standardising bodies from 101 WTO Member countries had notified their acceptance of the 'Code of Good Practice'. See List of Standardising Bodies that have accepted the Code of Good Practice for the Preparation, Adoption and Application of Standards.

21 See Panel Report, EC - Sardines, para. 7.60 and Appellate Body Report, EC - Sardines, para. 216. 


\subsection{Relationship with Other WTO Agreements}

\subsubsection{The SPS Agreement and the Agreement on Government Procurement}

As mentioned above, the scope of the TBT Agreement is determined by the type of measure. The TBT Agreement applies, in principle, to technical regulations, standards and conformity assessment procedures as defined in Annex 1 of the TBT Agreement. However, to avoid overlap with other WTO Agreements, the scope of application of the TBT Agreement has been limited in favour of two other WTO Agreements, the Agreement on Government Procurement and the SPS Agreement. The applicability of either of these agreements excludes the applicability of the TBT Agreement, even where the measures at issue are found to be in conformity with these agreements.

First, purchasing specifications related to the production or consumption of governmental bodies do not fall within the scope of the TBT Agreement when the Agreement on Government Procurement is applicable. ${ }^{22}$ The Agreement on Government Procurement addresses government purchases for their own use, which primarily consist of domestic goods and typically represent 10 to 15 per cent of GDP. Such purchases are outside the obligations of Article III:4 of the GATT $1994^{23}$, which prohibits treating imported goods less favourably than similar domestic products once the imported goods have entered the domestic market. The Agreement on Government Procurement requires that each Party must provide treatment of the products, services and suppliers of other Parties equal to that afforded to domestic products, services and suppliers. ${ }^{24}$ Note, however, that the Agreement on Government Procurement is a plurilateral agreement and its obligations apply only to the 38 Members party to the agreement ${ }^{25}$; the disciplines set out in this agreement do not apply to most WTO Members. ${ }^{26}$

Second, sanitary and phytosanitary measures which take the form of technical regulations, standards or conformity assessment procedures are excluded from the scope of the TBT Agreement as they fall under the more specific SPS Agreement. ${ }^{27}$ It is the purpose of the

22 Article 1.4 of the TBT Agreement.

23 See Article II:8(a) of the GATT 1994.

24 Agreement on Government Procurement. Article III, para. 1. Available at: http://www.wto.org/english/docs_e/legal_e/gpr-94_e.pdf, visited on 3 October 2005.

25 An additional 9 countries are negotiating accession. Available at: http://www.wto.org/english/tratop_e/gproc_e/memobs_e.htm, visited 3 October 2005.

26 P. Van den Bossche, The Law and Policy of the World Trade Organization (Cambridge University Press, 2005), 478-479.

27 Article 1.5 of the TBT Agreement. For further discussion of the definition of sanitary and phytosanitary measures, see below, Sec. 3.1.1. 
measure that qualifies it as a sanitary or phytosanitary measure. In EC - Hormones, the United States and Canada claimed, inter alia, that the measures at issue were inconsistent with the TBT Agreement. Referring to Article 1.5 of the TBT Agreement, the Panel found, however, that, since the measures at issue were SPS measures, the TBT Agreement did not apply at all in the $E C-$ Hormones dispute. ${ }^{28}$

\subsubsection{The GATT 1994}

The relationship between the GATT 1994 and the TBT Agreement is of a different nature and is not characterised by the exclusion of applicability of one of these agreements triggered by the applicability of the other one.

The Panel in EC - Asbestos held that in a case where both the GATT 1994 and the TBT Agreement appear to apply to a given measure, a panel must first examine whether the measure at issue is consistent with the TBT Agreement since this agreement deals 'specifically and in detail' with technical barriers to trade. ${ }^{29}$ However, should a panel find a measure to be consistent with the TBT Agreement, it must still examine whether the measure is also consistent with the GATT 1994.

Note, in general, that the relationship between the GATT 1994 and the other multilateral agreements on trade in goods (including the TBT Agreement) is governed by the General Interpretative Note to Annex 1A of the WTO Agreement. ${ }^{30}$ This provides that in case of conflict between a provision of the GATT 1994 and a provision of another multilateral agreement on trade in goods, the latter will prevail to the extent of the conflict. However, such a conflict between the TBT Agreement and the GATT 1994 is rather unlikely.

\subsection{Basic Substantive Provisions of the TBT Agreement}

The basic substantive provisions of the TBT Agreement contain several principles that are also found in the GATT 1994, such as: the most-favoured-nation (MFN) treatment obligation, the national treatment obligation and the obligation to refrain from creating unnecessary obstacles to international trade. In EC - Asbestos, the Appellate Body observed that the TBT Agreement intends to further the objectives of the GATT 1994. However, it

28 Panel Report, EC-Hormones (US), para. 8.29 and Panel Report, EC-Hormones (Canada), para. 8.32.

29 Panel Report, EC - Asbestos, para. 8.16. See on this point more generally, Appellate Body Report, ECBananas III, para. 204. 
immediately noted that the TBT Agreement does so through a specialised legal regime, containing different and additional obligations to those of the GATT 1994. ${ }^{31}$ This section examines the basic substantive provisions of the TBT Agreement relating to the following:

- MFN treatment;

- national treatment;

- the necessity requirement; and

- the use of international standards.

\subsubsection{MFN treatment and national treatment obligations}

Article 2.1 of the TBT Agreement provides that, with respect to technical regulations:

Members shall ensure that in respect of technical regulations, products imported from the territory of any Member shall be accorded treatment no less favourable than that accorded to like products of national origin and to like products originating in any other country.

The national treatment obligation and the MFN treatment obligation thus apply to technical regulations. $^{32}$ Pursuant to Annex $3 \mathrm{D}$ and Article 5.1.1 of the TBT Agreement, these obligations also apply to standards and conformity assessment procedures respectively. Thus, a requirement that tropical wood coming from Brazil be labelled as 'tropical wood', while there is no such requirement for tropical wood from African countries, would constitute a violation of the MFN treatment obligation set out in Article 2.1 of the TBT Agreement. Requiring accurate testing for the presence of GMOs in corn arriving from the United States, while such verification is not required for corn from Australia would constitute a violation of the MFN treatment obligation set out in Article 5.1.1 of the TBT Agreement. A requirement that imported furniture is fire-resistant, while no such requirement exists for domestically produced furniture, would constitute a violation of the national treatment obligation set out in Article 2.1 of the TBT Agreement.

31 See Appellate Body Report, EC - Asbestos, para. 80. Therefore, caution needs to be used when transposing interpretation given to these obligations under GATT 1994 to the similar provisions in the TBT Agreement. The different context, structure and formulation of the TBT Agreement's provisions can result in an interpretation that deviates from previously pronounced interpretations under the GATT 1994.

32 Note that with regard to technical regulations adopted by local government bodies or non-governmental bodies, Article 3 of the TBT Agreement requires Members to take such reasonable measures as may be available to them to ensure compliance by such bodies with the provisions of Article 2 . 
When establishing whether certain treatment is discriminatory, the determination of 'likeness' of the two products, which are subject to different treatment, is a prerequisite. The concept of 'like products' within the meaning of the relevant provisions of the TBT Agreement has not yet been the subject of dispute settlement proceedings. However, the concept of 'like products' has been clarified in panel and Appellate Body reports relating to Articles I and III of the GATT. ${ }^{33}$ This case law is undoubtedly instructive for the interpretation of the concept of 'like products' in the context of the TBT Agreement. Note, however, that it is generally accepted that the concept of 'like products' has different meanings in the different contexts in which it is used. In Japan - Alcoholic Beverages II, the Appellate Body illustrated the possible differences in the scope of the concept of 'like products', between different provisions of the WTO Agreement, by evoking the image of an accordion:

The accordion of 'likeness' stretches and squeezes in different places as different provisions of the WTO Agreement are applied. The width of the accordion in any one of those places must be determined by the particular provision in which the term 'like' is encountered as well as by the context and the circumstances that prevail in any given case to which that provision may apply. ${ }^{34}$

Note that in the GATT context a finding that products are like and given discriminatory treatment can be overcome by a justification of this discriminatory treatment on the basis of the Article XX exceptions. However, the 'rule-exception' relationship, which exists between, for example, Articles I and III of the GATT 1994, on the one hand, and Article XX of the GATT 1994, on the other hand, is not so clearly replicated in the TBT Agreement. The relationship between, for example, Articles 2.1 and 2.2 of the TBT Agreement remains to be clarified. $^{35}$

\subsubsection{Necessity test}

Article 2.2 of the TBT Agreement provides that, with respect to technical regulations:

Members shall ensure that technical regulations are not prepared, adopted or applied with a view to or with the effect of creating unnecessary obstacles to international trade.

33 See Report of the Working Party on Border Tax Adjustments, BISD 18S/97, para.18 which suggests "like products' must be determined on a case-by-case basis taking into account 'the product's end-uses in a given market; consumers' tastes and habits...the product's properties, nature and quality.'

34 Appellate Body Report, Japan - Alcoholic Beverages II, p. 21.

35 On Article 2.2 of the TBT Agreement, see below, Sec. 2.3.12. 
With respect to standards and conformity assessment procedures, Annex $3 \mathrm{E}$ and Article 5.1.2 of the TBT Agreement provide for the same obligation that such measures shall not be 'prepared, adopted or applied with the view to, or the effect of, creating unnecessary obstacles to trade'.

To ensure that technical regulations do not constitute unnecessary obstacles to trade, Article 2.2 of the TBT Agreement further requires that:

... technical regulations shall not be more trade-restrictive than necessary to fulfil a legitimate objective, taking account of the risks non-fulfilment would create.

Article 2.2 enumerates several legitimate objectives that may justify the creation of a trade obstacle in the form of a technical regulation. The list of legitimate policy objectives of Article 2.2 includes:

- national security;

- the prevention of deceptive practices;

- the protection of human health and safety, animal or plant life or health; and

- the protection of the environment.

As indicated by the words 'inter alia' in the introduction of the list, this list is not an exhaustive list of legitimate policy objectives. It will be up to panels and the Appellate Body to assess whether the policy objectives other than those listed are, in a particular case, legitimate policy objectives.

A technical regulation 'justified' under Article 2.2 as necessary to fulfil a legitimate policy objective at present will not automatically remain 'justified' in the future. Article 2.3 of the TBT Agreement provides that:

Technical regulations shall not be maintained if the circumstances or objectives giving rise to their adoption no longer exist or if the changed circumstances or objectives can be addressed in a less trade-restrictive manner.

Members thus continually have to assess the necessity of their technical regulations. They also have to continually assess whether their technical regulations are not more traderestrictive than necessary to fulfil a legitimate policy objective.

In assessing the necessity of their technical regulations, Members must, as is explicitly stated in Article 2.2 of the TBT Agreement, take 'account of the risks non-fulfilment would 
create. $^{36}$ It is clear that the risks of non-fulfilment of a technical regulation, aimed at meeting consumer preferences or avoiding deceptive practices, will be different from the risks that non-fulfilment of a regulation, aimed at the protection of human health, may entail. ${ }^{37}$ Other elements that, according to Article 2.2, may be useful to consider in assessing the necessity of a technical regulation include: available scientific and technical information; related processing technology; and intended end-uses of products. To date, there is no case law on the assessment of necessity under the TBT Agreement. However, in line with the case law on the assessment of necessity under Article XX(b) and (d) of the GATT 1994, it is to be expected that the assessment of necessity under the TBT Agreement will also involve a process of 'weighing and balancing' the above mentioned and other factors and elements.

\subsubsection{Use of international standards}

The harmonisation of national technical regulations and standards around international standards greatly facilitates the conduct of international trade. ${ }^{38}$ Harmonisation around international standards diminishes the trade restrictive effect of technical barriers to trade by minimising the variety of requirements that exporters have to meet in their different export markets thus making it possible for them to take advantage of economies of scale.

Thus, the TBT Agreement requires Members to base their technical regulations on international standards. Article 2.4 of the TBT Agreement provides in relevant part:

Where technical regulations are required and relevant international standards exist or their completion is imminent, Members shall use them, or the relevant parts of them, as a basis for their technical regulations ... ${ }^{39}$

36 With regard to conformity assessment procedure, Article 5.1.1. states that risks of non-conformity shall be taken into account. Annex 3.E (standards) does not contain the provision of risks to be taken into account.

37 As the TBT Agreement does not explicitly require a quantitative evaluation of risk, one could conclude, in line with the decision of the Appellate Body in EC - Asbestos with regard to Article XX(b) GATT (para. 167) and the Appellate Body in EC - Hormones with regard to the SPS Agreement (para. 186) (see below, Sec. 3.4.1), that an indication of risks in qualitative terms would suffice to justify a more traderestrictive measure. In addition, it is very likely that Members may rely on scientific sources which, although diverging from the majority scientific opinion, constitute a qualified and respected opinion (see Appellate Body Report, EC - Asbestos, para. 178).

38 Also the harmonisation of national conformity assessment procedures around international guides and recommendations for conformity assessment procedures facilitates international trade.

39 In view of this requirement, it is not surprising that Article 2.6 of the TBT Agreement requires Members to play a full part, within the limits of their resources, in the preparation of international standards for products for which they either have adopted, or expect to adopt, technical regulations. 
However, Article 2.4 further provides that Members do not have to base their technical regulations on international standards when:

... such international standards or relevant parts would be an ineffective or inappropriate means for the fulfilment of the legitimate objectives pursued, for instance because of fundamental climatic or geographical factors or fundamental technological problems.

The Panel and Appellate Body Reports in EC - Sardines illustrate the importance, as well as the contentious nature, of the requirement under Article 2.4 of the TBT Agreement that a technical regulation is based on an international standard. The first question that arose in this case was whether the international standard, 'Codex Stan 94' developed by an international food standard-setting body, the Codex Alimentarius Commission, constituted a relevant international standard for the purposes of Article 2.4. The Panel's examination of this question focused on whether the product coverage of the Codex Stan 94 was similar to that of the EC's technical regulation, the measure at issue. According to the Panel, the examination of relevance with regard to the subject matter entails an analysis of whether the Codex Stan 94 'bear[s] upon, relate[s] to or [is] pertinent to ${ }^{, 40}$ the EC's technical regulation. The European Communities argued that while the Codex Stan 94 deals with sardines and other sardine-type products, the EC's technical regulation exclusively concerns the product Sardina pilchardus. However, the Panel concluded that this argument was not sufficient to reject the relevance of Codex Stan 94 as an international standard, as both measures cover the same product (Sardina pilchardus) and include similar types of requirements in regard to this product such as labelling, presentation and packing medium.

Another question that arose in EC-Sardines was whether the EC's technical regulation was, as required by Article 2.4, based on the international standard. In line with the case law on the meaning of 'based on' in the SPS Agreement, the Panel in EC-Sardines concluded that the term 'based on' is not equivalent to the term 'conform to', but imposes the obligation to 'employ or apply' the international standard as 'the principal constituent or fundamental principle for the purpose of enacting the technical regulation'. ${ }^{41}$ According to the Appellate Body in EC-Sardines, this comes down to an analysis of "whether there is a contradiction between Codex Stan 94 and the EC regulation. ${ }^{42}$

\footnotetext{
40 Panel Report, EC-Sardines, para. 7.68.

41 Ibid., para. 7.110. On the meaning of 'based on' in the SPS Agreement, see below, Sec. 3.3.5 and Sec. 3.4 .1

42 Appellate Body Report, EC - Sardines, para. 249.
} 
As noted above, a technical regulation does not have to be based on the relevant international standard if that standard constitutes an inappropriate or ineffective means to achieve the legitimate objective pursued. In EC - Sardines, the Panel and the Appellate Body examined whether this exemption from the obligation to base the technical regulation on the relevant international standard was applicable.

A first step in this examination is whether a 'legitimate objective' is pursued. As indicated above, Article 2.2 of TBT Agreement contains a non-exhaustive list of legitimate policy objectives. The objectives pursued by the EC's technical regulation at issue in EC-Sardines, namely, the protection of market transparency, consumer protection and fair competition, are objectives not included in the list of Article 2.2. However, Peru, the complainant, did not contest the legitimacy of these objectives and the Panel thus refrained from ruling on their legitimacy. ${ }^{43}$

A second step in the examination of the applicability of the Article 2.2 exemption is whether the international standard is an inappropriate or ineffective means to achieve the legitimate objective(s) pursued by the technical regulation. According to the Appellate Body in EC Sardines, it is for the complainant to demonstrate that the international standard in question is both an effective and appropriate means to fulfil the legitimate objective. ${ }^{44}$ The difference between effectiveness and appropriateness is that 'the question of effectiveness bears upon the results of the means employed, whereas the question of appropriateness relates to the nature of the means employed. ${ }^{45}$ In other words, the international standard 'would be effective if it had the capacity to accomplish all ... objectives [pursued], and it would be appropriate if it were suitable for the fulfilment of all ... objectives [pursued]. ${ }^{46}$

Note that, as provided for in Article 2.5 of the TBT Agreement, a technical regulation that is adopted to achieve a legitimate objective explicitly enumerated in Article 2.2 and is in accordance with a relevant international standard, shall be presumed not to create an unnecessary obstacle to trade, as required by Article 2.2 discussed above. ${ }^{47}$ This means that in combination with the enumerated legitimate objectives under Article 2.2, international

43 The Panel, however, referred to the interpretation of the Panel in Canada - Pharmaceuticals Patents of the concept of 'legitimate interests' as 'a normative claim for protection of interests that are "justifiable" in the sense that they are supported by relevant public policies or other social norms' (Panel Report, EC - Sardines, para. 7.121).

44 See Appellate Body Report, EC-Sardines, para. 287.

45 Panel Report, EC-Sardines, para. 7.116.

46 Appellate Body Report, EC-Sardines, para. 288.

47 Article 2.5, TBT Agreement. 
standards have the function of exempting trade-restrictive technical regulations from the necessity requirement of the Article 2.2.

With regard to conformity assessment procedures, the TBT Agreement introduces similar requirements in Article 5.4. Member countries shall use the relevant guides or recommendations, existent or imminent, as a basis for their conformity assessment procedures unless the guide or recommendation is an inappropriate means to ensure conformity. Unlike Article 2.4, the criterion of effectiveness of the international guide or recommendation is not mentioned in Article 5.4.

\subsection{Other Substantive Provisions}

Apart from the basic substantive provisions discussed in the previous section, the TBT Agreement also contains a number of other substantive provisions which deserve to be mentioned. This section briefly examines the substantive provisions of the TBT Agreement relating to:

- equivalence and mutual recognition;

- product requirements in terms of performance; and

- transparency and notification.

\subsubsection{Equivalence and mutual recognition}

Article 2.7 of the TBT Agreement provides:

Members shall give positive consideration to accepting as equivalent technical regulations of other Members, even if these regulations differ from their own, provided they are satisfied that these regulations adequately fulfil the objectives of their own regulations.

The TBT Agreement thus requires WTO Members to consider accepting, as equivalent, the technical regulations of other Members. They should, however, only do so if they are satisfied that the foreign technical regulations adequately fulfil the legitimate objectives pursued by their own technical regulations.

With regard to conformity assessment procedures, Article 6.1 of the TBT Agreement requires Members to accept the results of such procedures by other Member countries, even if their 
conformity assessment procedures differ, as long as they provide an assurance of conformity with the domestic technical regulations or standards. Compliance with international guides and recommendations on conformity assessment procedures shall be taken into consideration when evaluating the adequacy of the competent conformity assessment bodies. Members are encouraged to enter into negotiations for the conclusion of agreements acknowledging mutual recognition of the results of each other's conformity assessment procedures. ${ }^{48}$

Article 9 of the TBT Agreement encourages the adoption of, and participation in, international and regional systems for conformity assessment. Such systems aim for cooperation between national certification bodies of Members and often take the form of multilateral recognition agreements. Examples of such international or regional systems are the International Accreditation Forum (IFA) or the Worldwide System for Conformity Testing and Certification of Electrical Equipment (IECEE).

\subsection{2. $\quad$ Product requirements in terms of performance}

With respect to technical regulations, Article 2.8 of the TBT Agreement provides:

Wherever appropriate, Members shall specify technical regulations based on product requirements in terms of performance rather than design or descriptive characteristics.

The TBT Agreement thus prefers Members to adopt technical regulations on the basis of product requirements in terms of performance. With regard to standards, Annex 3 I of the TBT Agreement provides for the same preference for standards based on product requirements in terms of performance.

\subsubsection{Transparency and notification}

When no relevant international standard exists or when a proposed technical regulation is not in accordance with a relevant international standard and the proposed technical regulation may have a significant effect on trade of other Members, Article 2.9 of the TBT Agreement requires Members to:

- publish a notice, at an early stage, in such a manner as to enable interested parties in other Member states to become acquainted with the proposed technical requirement;

\footnotetext{
48 See Article 6.3 of the TBT Agreement.
} 
- notify other Members through the WTO Secretariat of the products to be covered by the proposed technical regulation, together with a brief indication of the objective and rationale of the technical regulation. This notification must be done at an early stage of the process, when amendments to the proposed technical regulation can still be made and comments can be taken into account;

- provide other Members, upon their request, with copies of and information on the proposed technical regulation, including information on how the proposed technical regulation deviates from relevant international standards; and

- allow a reasonable time for other Members to make comments on the proposed technical regulation, to discuss these comments upon request, and to take the comments and the resulting discussion into account when eventually deciding on the technical regulation.

When a technical regulation is adopted to address an urgent problem of safety, health, environmental protection or national security, a Member may set aside the notification (and consultation) requirements set out in Article 2.9 of the TBT Agreement. However, in such instances, Members are subject to certain notification (and consultation) obligations after the adoption of the technical regulation. ${ }^{49}$

Article 2.11 of the TBT Agreement requires that all adopted technical regulations are:

... published promptly or otherwise made available in such a manner as to enable interested parties in other Members to become acquainted with them.

Except when a technical regulation addresses an urgent problem as referred to above, technical regulations may not enter into force immediately after publication. Article 2.12 of the TBT Agreement provides in relevant part:

... Members shall allow a reasonable interval between the publication of technical regulation and their entry into force in order to allow time for producers in exporting Members ... to adapt their products or methods of production to the requirements of the importing Member.

Such a reasonable interval between the publication and the entry into force of a technical regulation is particularly important for producers in exporting developing country Members.

49 See Article 2.10 of the TBT Agreement. 
The TBT Agreement contains similar provisions with regard to the notification of standards and conformity assessment requirements. ${ }^{50}$ As an additional requirement for standards, the TBT Agreement requires Members' national standardising bodies to publish, at least every six months, their work programme and report on the progress regarding the preparation and adoption of standards. ${ }^{51}$

Furthermore, Article 10 of the TBT Agreement requires each Member to establish an enquiry point which will answer enquiries of other Members and which will provide relevant documentation related to adopted technical regulations, standards and conformity assessment procedures.

\subsection{Institutional and Procedural Provisions of the TBT Agreement}

In addition to the substantive provisions discussed above, the TBT Agreement also contains a number of institutional and procedural provisions. This section deals with the provisions on:

- the TBT Committee; and

- dispute settlement.

\subsubsection{TBT Committee}

The TBT Agreement established a Committee on Technical Barriers to Trade, commonly referred to as the 'TBT Committee'. 52 This Committee is composed of representatives of all WTO Members and meets when necessary. ${ }^{53}$ The function of the TBT Committee is to provide Members with a forum for consultations regarding any matters pertaining to the operation or objectives of the TBT Agreement. It must also undertake an annual review of the implementation and operation of the Agreement (annual reviews). ${ }^{54}$ Moreover, at the end of every three-year period, the TBT Committee undertakes an in-depth review of the operation of the Agreement (triennial reviews). At that time, the TBT Committee may recommend amendments to the rights and obligations contained in the Agreement if this is considered

50 Annex $3 \mathrm{~L}, \mathrm{M}, \mathrm{N}$ and $\mathrm{O}$ of the TBT Agreement (for standards) and Articles 5.6, 5.75 .8 and 5.8 of the TBT Agreement (for conformity assessment procedures).

51 See Annex $3 \mathrm{~J}$ of the TBT Agreement.

52 See Article 13.1 of the TBT Agreement.

53 Pursuant to Article 13.1 of the TBT Agreement, the TBT Committee has to meet at least once a year. In fact, in 2004, it met 6 times.

54 See Article 15.2 of the TBT Agreement. 
necessary 'to ensure mutual economic advantage and balance of rights and obligations' ${ }^{55}$ To date, the TBT Committee has undertaken three triennial reviews, the last of which took place in $2003 .{ }^{56}$ None of these reviews has resulted in any recommendation for amendment to the TBT Agreement.

\subsubsection{Dispute settlement}

Consultations and the settlement of disputes with respect to any matter affecting the operation of the TBT Agreement shall follow the provisions of Articles XXII and XXIII of the GATT 1994 as elaborated on and applied by the Dispute Settlement Understanding (DSU). ${ }^{57}$ The TBT Agreement contains a few 'special or additional rules and procedures' set out in Articles 14.2, 14.3, 14.4 and Annex 2 of the TBT Agreement. ${ }^{58}$ These 'special or additional rules and procedures' prevail over the rules and procedures of the DSU to the extent that they differ. ${ }^{59}$ Pursuant to Article 14.2 of the TBT Agreement, a panel, charged with the settlement of a dispute under the TBT Agreement may establish at the request of one of the parties to the dispute or at its own initiative, a technical expert group to assist the Panel in questions of a technical nature. As stated in Article 14.3, such a technical expert group is governed by the procedures set out in Annex 2 of the TBT Agreement. The panel in question shall define the composition, terms of reference and working procedures of the expert group it has established. The members of a technical expert group shall be persons of professional standing and of relevant experience and shall not include citizens or government officials of a Member that is party to the dispute. The technical expert group may seek any information and technical advice it deems appropriate. It shall inform the Member under whose jurisdiction the sought information or technical advice is located. Except when the information provided to the technical expert group is of a confidential nature, the parties to the dispute shall have access to that information. ${ }^{60}$ To date, panels have not yet made use of the possibility to establish a technical expert group.

As mentioned above, not only central government bodies but also local government and nongovernmental entities may adopt and apply technical regulations, standards and conformity

55 See Article 15.4 of the TBT Agreement.

56 Committee on Techincal Barriers to Trade, Third Triennial Review of the Operation and Implementation of the Agreement on Technical Barriers to Trade, G/TBT/13, dated 11 November 2003.

57 See Article 14.1 of the TBT Agreement. For a detailed discussion of the WTO dispute settlement system, see P. Van den Bossche, The Law and Policy of the World Trade Organization (Cambridge University Press, 2005), Chapter 3: WTO Dispute Settlement.

58 See Appendix 2 of the DSU.

59 See Article 1.2 of the DSU.

60 See Annex 2 of the TBT Agreement. 
assessment procedures. Articles 3, 4, 7, 8 and 9 of the TBT Agreement impose certain obligations on Members with regard to the conduct of these local government and nongovernmental entities. Article 14.4 of the TBT Agreement provides:

The dispute settlement provisions set out above can be invoked in cases where a Member considers that another Member has not achieved satisfactory results under Articles 3, 4, 7, 8 and 9 and its trade interests are significantly affected. In this respect, such results shall be equivalent to those as if the body in question were a Member.

\subsection{Special Provisions for Developing Countries}

As with many other WTO agreements, the TBT Agreement takes into account the specific situation of developing country Members and the problems they may encounter in complying with the obligations of the TBT Agreement. This section discusses:

- technical assistance for developing country Members; and

- provisions providing for special and differential treatment.

2.6.1.

Technical assistance

Pursuant to Article 11 of the TBT Agreement, Members shall, upon request, advise or provide technical assistance to the requesting Member, in particular to least-developed country Members. The advice and technical assistance referred to in Article 11 primarily concern assistance in establishing institutions or legal frameworks dealing with the preparation of technical regulations and standards and the development of conformity assessment procedures. In addition, requested Members shall assist the requesting Member in achieving the following objectives:

- participation in international standardisation bodies;

- access to their systems of conformity assessment; and

- becoming a member of, or participating in, international or regional systems for conformity assessment.

At its Doha Session, the Ministerial Conference placed emphasis on the need to facilitate effective participation of least-developed country Members in different levels of the 
development of international standards. ${ }^{61}$ To this end, cooperation with the relevant international organisations will continue to address the need for technical assistance. Furthermore, Members are urged to provide financial and technical assistance to facilitate least developed country Members to meet the requirements of any newly introduced TBT measure that may have a significant negative trade effect.

\subsection{2. $\quad$ Special and differential treatment}

Although the TBT Agreement does not foresee a special transition period for developing country Members, Article 12.8 explicitly recognises the difficulty developing country Members may face in implementing their obligations under the TBT Agreement. Consequently, the TBT Committee may grant, upon request, time-limited exceptions, in whole or in part, from such obligations. In addition, developing country Members do not have to base their technical regulations, standards or conformity assessment procedures on international standards, if the international standards are not appropriate to their development or financial and trade needs, with particular attention to the preservation of indigenous technology and production methods and processes compatible with their development needs. Furthermore, Members shall also ensure that the international standardising bodies shall pay attention to the possibility of developing international standards with regard to products of special interest to developing country members.

\section{THE SPS AGREEMENT}

As mentioned above, within the general category of technical barriers to trade, a specific category of measures can be identified, namely, sanitary and phytosanitary measures. These are measures aimed at the protection of human, animal or plant life or health from certain specified risks. The negotiators of the WTO agreements considered that these measures merited special attention due to their close link to agricultural trade, a sector of trade notoriously difficult to liberalise. As a result, sanitary and phytosanitary measures are dealt with in a separate agreement, the Agreement on the Application of Sanitary and Phytosanitary Measures, commonly referred to as the SPS Agreement.

61 See Decision of the Ministerial Conference, Implementation related issues and concerns, WT/MIN(01)/17 dated 20 November 2001, para. 5.3. 
This section deals with:

- the scope of application of the SPS Agreement;

- the relationship between the SPS Agreement and other WTO agreements;

- the basic principles of the SPS Agreement;

- risk analysis obligations under the SPS Agreement;

- other substantive, institutional and procedural provisions of the SPS Agreement; special provisions for developing countries. ${ }^{62}$

\subsection{Scope of Application of the SPS Agreement}

With regard to the scope of application of the SPS Agreement, this section distinguishes between:

- the substantive scope of application, i.e., the types of measures to which the agreement applies;

- the personal scope of application, i.e. the entities to which the Agreement applies;

- and the temporal scope of application of the agreement.

\subsubsection{Substantive scope of application}

The disciplines referenced in the SPS Agreement do not cover all measures for the protection of human, plant or animal life or health but, rather, apply to a clearly circumscribed set of measures. The substantive scope of application of the SPS Agreement is set out in Article 1.1, which provides in relevant part:

This Agreement applies to all sanitary and phytosanitary measures which may, directly or indirectly, affect international trade.

For a measure to be subject to the SPS Agreement, therefore, it must be:

- a sanitary or phytosanitary measure; and

- a measure that may affect international trade.

A sanitary or phytosanitary measure or 'SPS measure' is defined in paragraph 1 of Annex A of the SPS Agreement as:

\footnotetext{
62 I am much indebted to Ms. Denise Prévost for contributing this section on the SPS Agreement.
} 
Any measure applied:

(a) to protect animal or plant life or health within the territory of the Member from risks arising from the entry, establishment or spread of pests, diseases, disease-carrying organisms or disease-causing organisms;

(b) to protect human or animal life or health within the territory of the Member from risks arising from additives, contaminants, toxins or disease-causing organisms in foods, beverages or feedstuffs;

(c) to protect human life or health within the territory of the Member from risks arising from diseases carried by animals, plants or products thereof, or from the entry, establishment or spread of pests; or

(d) to prevent or limit other damage within the territory of the Member from the entry, establishment or spread of pests.

From this definition, it is clear that the question of whether a measure is an 'SPS measure,' depends on its purpose or aim. In broad terms, an 'SPS measure' is one that:

- aims at the protection of human or animal life or health from food-borne risks; or

- aims at the protection of human, animal or plant life or health from risks from pests or diseases.

Note that the definitions in Annex A refer specifically to the protection of human, animal or plant life or health 'within the territory of the Member', thus excluding measures aimed at extra-territorial health protection from the scope of application of the SPS Agreement.

Note also that an SPS measure may take any one of a broad range of forms including laws, decrees, regulations, requirements and procedures. Thus, once a measure aims at one of the goals listed in sub-paragraphs (a) to (d) of the definition set out in paragraph 1 of Annex A, it is covered by the SPS Agreement regardless of the specific form it takes.

The second requirement for the application of the SPS Agreement according to Article 1.1 is that the measure at issue 'may directly or indirectly affect international trade'. This requirement is easy to fulfill, as any measure that applies to imports can be said to affect international trade. Moreover, Article 1.1 only requires that the measure 'may' affect international trade. Hygiene requirements for street food vendors is arguably an example of an SPS measure which does not fall within the scope of application of the SPS Agreement because it does not - actually or potentially - affect international trade. When a measure is an 
SPS measure and affects international trade, actually or potentially, that measure falls within the substantive scope of application of the SPS Agreement. ${ }^{63}$

\subsubsection{Personal scope of application}

The adoption and implementation of SPS measures may sometimes be in the hands of bodies other than central government such as regulatory agencies, regional bodies and sub-federal governments. The SPS Agreement takes this into account by providing, in Article 13, that Members are fully responsible for the implementation of the Agreement and must enact and implement positive measures to ensure the observance of its rules by bodies other than central government bodies. The Panel in Australia - Salmon (Article 21.5) held that the sanitary measures taken by the government of Tasmania were subject to the SPS Agreement and fell under the responsibility of Australia. ${ }^{64}$

Members must take all reasonable measures available to them to ensure that local and regional government bodies as well as non-governmental bodies in their territories comply with the SPS Agreement. Members may not rely on non-governmental bodies to implement their SPS measures unless these bodies comply with the SPS Agreement.

\subsubsection{Temporal scope of application}

The question of whether the SPS Agreement is applicable to SPS measures adopted and/or applied before the entry into force of the agreement was raised by the European Communities in EC-Hormones. The Appellate Body answered as follows:

If the negotiators had wanted to exempt the very large group of SPS measures in existence on 1 January 1995 from the disciplines of provisions as important as Articles 5.1 and 5.5, it appears reasonable to us to expect that they would have said so explicitly. Articles 5.1 and 5.5 do not distinguish between SPS measures adopted before 1 January 1995 and measures adopted since; the relevant implication is that they are intended to be applicable to both. ${ }^{65}$

63 As the Panel in EC - Hormones noted, there are no additional requirements for the applicability of the SPS Agreement. Contrary to what the European Communities argued in that case, the SPS Agreement contains, in particular, no requirement of a prior violation of a provision of GATT (see Panel Report EC - Hormones (Canada), para. 8.39; and Panel Report EC-Hormones (US), para.8.36).

64 Panel Report, Australia - Salmon (Article 21.5) para. 7.13.

65 Appellate Body Report, EC - Hormones para. 128. 
Therefore, Members have to review all of their existing SPS measures in the light of the disciplines of the SPS Agreement.

\subsection{Relationship with other WTO Agreements}

The SPS Agreement is not the only WTO agreement of relevance to measures for the protection of human, animal or plant life or health. The GATT 1994 and the TBT Agreement obviously also contain rules applicable to such measures. The position of health measures, under WTO law, is thus determined within their respective spheres of application by all three of these agreements. It is therefore necessary to examine the relationship between the SPS Agreement and the other relevant WTO agreements.

\subsubsection{The TBT Agreement}

The TBT Agreement, as discussed earlier in this paper, applies to technical regulations, standards and conformity assessment procedures in general, including those aiming at the protection of human, animal or plant life or health. Clearly, SPS measures may often take the form of technical regulations, standards or conformity assessment procedures. As the rules of the SPS Agreement are in some respects stricter than those of the TBT Agreement, it could be to the advantage of a complaining Member to challenge a measure under the SPS Agreement rather than the TBT Agreement. However, this choice is not left to Members. As already discussed above and as explicitly set out in Article 1.5 of the TBT Agreement, the TBT Agreement does not apply to SPS measures. ${ }^{66}$ When a measure is an 'SPS measure', as defined in Annex A of the SPS Agreement, the SPS Agreement applies to the exclusion of the TBT Agreement, even if the measure would otherwise be considered a 'technical regulation, standard or conformity assessment procedure' for purposes of the TBT Agreement. The relationship between the SPS Agreement and the TBT Agreement can thus be described as one of mutual exclusivity.

\subsubsection{The GATT 1994}

Contrary to the situation with respect to the TBT Agreement, no relationship of mutual exclusivity exists between the SPS Agreement and the GATT 1994. It is thus possible for a

66 See above, Sec. 2.2.1. 
measure to be caught by the GATT disciplines as well as those of the SPS Agreement. Broadly speaking, the GATT 1994 would catch those SPS measures that are discriminatory or constitute quantitative restrictions to imports, in which case the measures would need to be justified under the exception contained in Article $\mathrm{XX}(\mathrm{b})$ with respect to health protection measures. Although one of the motives behind the negotiation of the SPS Agreement was the need to clarify and flesh out the Article $\mathrm{XX}(\mathrm{b})$ exception, it is important to note that the SPS Agreement goes much further than a mere elaboration of Article $\mathrm{XX}(\mathrm{b})^{67}$ by imposing a new and comprehensive set of rules. However, this new Agreement did not replace the relevant GATT rules. Thus a measure that falls within the definition of an 'SPS measure' under Annex A of the SPS Agreement and is thus subject to the rules of the SPS Agreement may, to the extent that it is discriminatory or constitutes a quantitative restriction also be caught, in principle, by the rules of the GATT.

As already noted above, the relationship between the GATT 1994 and other the multilateral agreements on trade in goods (including the SPS Agreement) is governed by the General Interpretative Note to Annex 1A of the WTO Agreement. ${ }^{68}$ This provides that in case of conflict between a provision of the GATT 1994 and a provision of another multilateral agreement on trade in goods, the latter will prevail to the extent of the conflict. However, a conflict between the SPS Agreement and the GATT 1994 is rather unlikely as the SPS Agreement includes the existing GATT disciplines relevant to health measures. This is reflected in the fact that Article 2.4 of the SPS Agreement contains a presumption of consistency with the relevant provisions of the GATT 1994 for all measures that are in conformity with the SPS Agreement. Thus, it would be logical, in a dispute involving an SPS measure, to begin by examining the measure's conformity with the rules of the SPS Agreement before examining its compliance with the GATT 1994. This is supported by the finding of the Panel in EC - Hormones, which held:

The SPS Agreement specifically addresses the type of measure in dispute. If we were to examine GATT first, we would in any event need to revert to the SPS Agreement: if a violation of GATT were found, we would need to consider whether Article XX(b) could be invoked and would then necessarily need to examine the SPS Agreement; if, on the other hand, no GATT violation were found, we would still need to examine the consistency of the measure with the SPS Agreement since nowhere is consistency with GATT presumed to be

67 This was recognised by the Panel in EC - Hormones (see Panel Report, EC - Hormones (Canada) para. 8.41; and Panel Report, EC - Hormones ( $U S$ ) para.8.38). 
consistency with the SPS Agreement. For these reasons, and in order to conduct our consideration of this dispute in the most efficient manner, we shall first examine the claims raised under the SPS Agreement. ${ }^{69}$

\subsection{Basic Principles of the SPS Agreement}

The basic principles of the SPS Agreement, contained in Articles 2 and 3 thereof, reflect the underlying aim of addressing the need to increase market access for food and agricultural products with the recognition of the sovereign right of governments to take measures to protect human, animal and plant life and health in their territories. This section discusses the following basic principles of the SPS Agreement:

- the sovereign right of WTO Members to take SPS measures;

- the obligation to take or maintain only SPS measures necessary to protect human, animal or plant life or health (the 'necessity requirement');

- the obligation to take or maintain only SPS measures based on scientific principles and on sufficient scientific evidence (the 'scientific disciplines');

- the obligation not to adopt or maintain SPS measures that arbitrarily or unjustifiably discriminate or constitute a disguised restriction on trade; and

- the obligation to base SPS measures, as much as possible and appropriate, on international standards (the 'goal of harmonisation').

\subsection{1. $\quad$ Right to take SPS measures}

It is significant that the SPS Agreement, in Article 2.1, expressly recognises the right of Members to take SPS measures necessary for the protection of human, animal or plant life or health. This differs from the position of health measures under GATT rules where discriminatory measures or quantitative restrictions are in principle prohibited; justification for such measures must be found under Article XX(b). This has important implications for the burden of proof in dispute settlement proceedings. Under the GATT 1994, a Member imposing a discriminatory health measure or one that constitutes a quantitative restriction bears the burden of proof to show that it complies with the requirements of the Article $\mathrm{XX}(\mathrm{b})$ exception. On the contrary, under the SPS Agreement, the complaining Member must show that the measure is inconsistent with the rules of the SPS Agreement. ${ }^{70}$

\footnotetext{
69 Panel Report, EC - Hormones (Canada), para. 8.45; Panel Report, EC - Hormones (US), para.8.42.

70 See Appellate Body Report, EC-Hormones, para. 98.
} 
The right to take SPS measures is, however, not unlimited but is subject to the disciplines contained in the rest of the SPS Agreement. The basic disciplines can be found in Article 2.2 and 2.3, and are elaborated in later provisions of the SPS Agreement. These provisions take on board the existing GATT rules applicable to health measures and introduce new scientific requirements for the use of SPS measures.

\subsubsection{Necessity requirement}

As set forth in Article 2.2 of the SPS Agreement, the sovereign right of Members to take SPS measures is, first of all, limited by the requirement that:

... any sanitary or phytosanitary measure is applied only to the extent necessary to protect human, animal or plant life and health ...

This 'necessity' requirement clearly reflects the familiar 'necessity' requirement contained in Article XX(b) of the GATT 1994, the health policy exception in the GATT $1994 .^{71}$ This requirement has been elucidated in case law. The Panel in Thailand-Cigarettes ${ }^{72}$ defined a measure as necessary when there is no alternative measure consistent with GATT obligations that a Member could be expected to employ in order to achieve the desired public health objective. The Panel in US-Gasoline further clarified that the requirement of necessity under Article $\mathrm{XX}(\mathrm{b})$ does not examine the necessity of the state's policy objective, but rather the necessity of the disputed measure to achieve that objective. ${ }^{73}$

The necessity requirement in Article 2.2 has not yet been subject to interpretation in dispute settlement. As this requirement is made more specific in other provisions of the SPS Agreement, Members prefer to challenge SPS measures under these more specific provisions. $^{74}$

72 Panel Report, Thailand-Cigarettes, para. 15.

73 Panel Report, US-Gasoline, para. 6.22.

74 See below, Sec. 3.4.2. An example of such a more specific provision is Article 5.6 of the SPS Agreement, which requires, as discussed below, that SPS measures are not more trade-restrictive than required to achieve their policy objective. 


\subsection{3. $\quad$ Scientific disciplines}

Article 2.2 of the SPS Agreement also introduces new scientific disciplines for the use and maintenance of SPS measures. It requires that:

... any sanitary or phytosanitary measure ... is based on scientific principles and is not maintained without sufficient scientific evidence, except as provided for in paragraph 7 of Article 5.

These requirements introduce science as the touchstone against which SPS measures will be judged. These scientific requirements are further elaborated on in Article 5.1 which provides that SPS measures must be based on a risk assessment. With regard to these scientific disciplines, the Appellate Body in EC - Hormones held:

...The requirements of a risk assessment under Article 5.1, as well as of 'sufficient scientific evidence' under Article 2.2, are essential for the maintenance of the delicate and carefully negotiated balance in the SPS Agreement between the shared, but sometimes competing interests of promoting international trade and of protecting the life and health of humans... ${ }^{75}$

The Panel in Japan - Apples was the first to consider the meaning of the term 'scientific' and the term 'evidence' in Article 2.2. ${ }^{76}$ It held that for evidence to be qualified as 'scientific' it must be gathered through scientific methods ${ }^{77}$ and it favoured relying on scientifically produced evidence rather than purely circumstantial evidence. ${ }^{78}$ With regard to the term 'evidence' the Panel held:

... Negotiators could have used the term "information", as in Article 5.7, if they considered that any material could be used. By using the term "scientific evidence", Article 2.2 excludes in essence not only insufficiently substantiated information, but also things as a non-demonstrated hypothesis. ${ }^{79}$

The Panel noted that it would equally consider both direct and indirect scientific evidence, although their probative value would differ. ${ }^{80}$

The issue of what is meant by 'sufficient scientific evidence' was addressed for the first time in Japan - Agricultural Products II. In that case, the Appellate Body held that it requires a

\footnotetext{
75 Appellate Body Report, EC - Hormones, para. 177.

76 Panel Report, Japan - Apples, paras 8.91-8.98

77 Ibid., para. 8.92.

78 Ibid., para. 8.95, where it quoted a statement to this effect by a panel expert.

79 Ibid., para. 8.93.

$80 \quad$ Ibid., para. 8.98.
} 
rational relationship between the SPS measure and the scientific evidence. The Appellate Body ruled as follows:

... we agree with the Panel that the obligation in Article 2.2 that an SPS measure not be maintained without sufficient scientific evidence requires that there be a rational or objective relationship between the SPS measure and the scientific evidence. Whether there is a rational relationship between an SPS measure and the scientific evidence is to be determined on a case-by-case basis and will depend upon the particular circumstances of the case, including the characteristics of the measure at issue and the quality and quantity of the scientific evidence. $^{81}$

It is thus clear that panels have some discretion in determining whether a 'rational relationship' between the measure and the scientific evidence exists, in the light of the particular circumstances of each case. It would seem that where reputable scientific support for a measure exists, the requirement of 'sufficient scientific evidence' would be met.

Moreover, in EC - Hormones the Appellate Body noted that in determining whether sufficient scientific evidence exists, panels should:

... bear in mind that responsible, representative governments commonly act from perspectives of prudence and precaution where risks of irreversible, e.g. life-terminating, damage to human health are concerned.' ${ }^{82}$

Thus, the more serious the risks to life or health, the less demanding the requirement of 'sufficient scientific evidence'.

In Japan - Apples, the Panel further elaborated on the 'rational relationship' test by introducing a proportionality criterion into Article 2.2. It found, on the evidence before it, that the risk of transmission of fire blight through the importation of apple fruit was negligible, ${ }^{83}$ and contrasted this with the requirements composing the measure at issue. It found the measure at issue to be clearly disproportionate to the risk and thus a violation of Article 2.2. ${ }^{84}$ The Appellate Body did not take issue with this proportionality test and noted that:

\footnotetext{
81 Appellate Body Report, Japan - Agricultural Products, para. 84.

Appellate Body Report, EC - Hormones, para. 124.

83 Panel Report, Japan - Apples, para. 8.169.

84 Panel Report, Japan-Apples, para. 8.198.
} 
...for the Panel, such "clear disproportion" implies that a "rational or objective relationship" does not exist between the measure and the relevant scientific evidence, and, therefore, ... that the measure is maintained "without sufficient scientific evidence" within the meaning of Article 2.2 of the SPS Agreement. ${ }^{85}$

The Appellate Body further supported the Panel's role in assessing the outcome of the proportionality test by rejecting Japan's contention that the Panel should have accorded Japan a "certain degree of discretion" in the way in which it chose, weighed and evaluated the scientific evidence. The Appellate body stated that deference by panels to the findings of national authorities would not be compatible with the standard of review ${ }^{86}$ applicable to panels. $^{87}$

Pursuant to Article 2.2 of the SPS Agreement, quoted above, SPS measures must not be maintained without sufficient scientific evidence, except as provided for under Article 5.7. This provision, discussed in more detail below, deals with a situation in which there is insufficient scientific information. Governments are sometimes faced with situations where they need to act to prevent a possible risk despite insufficient scientific data regarding the existence and likelihood of the risk. Article 2.2 takes account of this fact by expressly referring to Article 5.7 which allows for provisional SPS measures to be taken. The relationship between Articles 2.2 and 5.7 was set out by the Appellate Body in Japan Agricultural Products II as follows:

$\ldots$ it is clear that Article 5.7 of the SPS Agreement, to which Article 2.2 explicitly refers, is part of the context of the latter provision and should be considered in the interpretation of the obligation not to maintain an SPS measure without sufficient scientific evidence. Article 5.7 allows Members to adopt provisional SPS measures "in cases where relevant scientific evidence is insufficient" and certain other requirements are fulfilled. Article 5.7 operates as a qualified exemption from the obligation under Article 2.2 not to maintain SPS measures without sufficient scientific evidence. An overly broad and flexible interpretation of that obligation would render Article 5.7 meaningless. ${ }^{88}$

The existence of Article 5.7 thus argues against an overly broad and flexible interpretation of the obligation of Article 2.2, that SPS measures should not be maintained without sufficient scientific evidence.

85 Appellate Body Report, Japan - Apples, para. 163.

86 It is well-established case law that the standard of review to be applied by panels is that of an "objective assessment" of the matter, which implies neither total deference by panels to national authorities' determinations, nor de novo review.

87 Appellate Body Report, Japan-Apples, para. 165.

88 Appellate Body Report, Japan - Agricultural Products II, para. 80. 
Note that the basic scientific disciplines contained in Article 2.2 are further specified in Articles 5.1 and 5.2 of the SPS Agreement, which require - as discussed below - that SPS measures be based on a risk assessment, taking into account certain factors. ${ }^{89}$

\subsubsection{No arbitrary or unjustifiable discrimination or disguised restriction on trade}

A third basic limitation on a Member's right to impose SPS measures can be found in Article 2.3 of the SPS Agreement. Article 2.3 reflects the familiar GATT non-discrimination obligations contained in Articles I:1 and III:4 of the GATT 1994 as well as the chapeau of Article XX thereof. ${ }^{90}$ Article 2.3 provides:

Members shall ensure that their sanitary and phytosanitary measures do not arbitrarily or unjustifiably discriminate between Members where identical or similar conditions prevail, including between their own territory and that of other Members. Sanitary and phytosanitary measures shall not be applied in a manner which would constitute a disguised restriction on international trade.

Article 2.3 was at issue in Australia - Salmon (Article 21.5), where Canada claimed that Australia violated this provision by insisting on import requirements for salmonids from Canada but providing no internal control measures on the movement of dead Australian fish. The Panel identified three cumulative requirements that must be met for a violation of Article 2.3 to be established, namely that:

- the measure discriminates between the territories of Members other than the Member imposing the measure, or between the territory of the Member imposing the measure and another Member;

- the discrimination is arbitrary or unjustifiable; and

- identical or similar conditions prevail in the territory of the Members compared. ${ }^{91}$

Further, the Panel in Australia - Salmon (Article 21.5) noted that discrimination in the sense of the first element of Article 2.3 includes discrimination between different products (in this

89 See below, Sec. 3.4.2 and Appellate Body Report, EC - Hormones, para. 180. As the Appellate Body noted in Australia - Salmon, Article 2.2 is more general than Articles 5.1 and 5.2, and a violation of Article 2.2 can thus exist independently of a violation of Articles 5.1 and 5.2 (see Appellate Body Report, Australia - Salmon, para. 137)

90 Ibid., para. 251.

91 Panel Report, Australia - Salmon (Article 21.5), para. 7.111. 
case salmonids from Canada and other dead fish from Australia). ${ }^{92}$ This differs significantly from the GATT non-discrimination rules that apply only to 'like' or 'directly competitive or substitutable' products. ${ }^{93}$ The broader scope of Article 2.3 takes into account that dissimilar products may pose the same or similar health risks and should therefore be treated in the same way. For example, different animals may be carriers of foot and mouth disease and should thus be subject to the same measures where this risk is present. This broad prohibition on discriminatory treatment is tempered by the other two requirements that must be met before a violation of Article 2.3 exists. Thus, if the different treatment can be justified or if conditions in the Members compared are not similar or identical, Article 2.3 is not violated. In this regard, the Panel in Australia - Salmon (Article 21.5) was not convinced that 'identical or similar' conditions prevailed in Australia and Canada, as there was a substantial difference in the disease status of these two Members. ${ }^{94}$

The basic discipline in Article 2.3 finds reflection in the more specific prohibition in Article 5.5 on arbitrary or unjustifiable distinctions in the levels of protection chosen by a Member in different situations, where these distinctions lead to discrimination or disguised restrictions on trade. ${ }^{95}$ A violation of Article 5.5 will necessarily imply a violation of Article 2.3 , but the opposite is not true as Article 2.3 is broader than Article 5.5. ${ }^{96}$

\subsubsection{The goal of harmonisation}

Due to the different factors that regulators take into account when enacting SPS measures (national consumer preferences, industry interests, geographic and climatic conditions etc.) there are large differences in SPS measures across countries. The resulting wide variety of SPS measures that exporters face on their different export markets has a negative impact on market access for their products, as exporters will have to adjust products to the many different SPS measures. The SPS Agreement addresses this problem in Article 3 by

\footnotetext{
92 Ibid., para. 7.112.

93 See above, Sec. 2.3.1, for a description of "like products" under GATT 1994.

94 Panel Report, Australia - Salmon (Article 21.5), para. 7.113.

95 See below, Sec. 3.4.2.

96 Appellate Body Report, para. 252; and Panel Report, Australia - Salmon (Article 21.5), para. 8.160.
} 
encouraging, but not obliging, Members to harmonise their SPS measures around international standards. ${ }^{97}$

The aim of Article 3 of the SPS Agreement was expressed as follows by the Appellate Body in EC - Hormones:

In generalized terms, the object and purpose of Article 3 is to promote the harmonization of the SPS measures of Members on as wide a basis as possible, while recognizing and safeguarding, at the same time, the right and duty of Members to protect the life and health of their people. ${ }^{98}$

Under Article 3, Members have three autonomous options with regard to international harmonised standards, each with its own consequences. Members may choose to:

- base their SPS measures on international standards according to Article 3.1;

- conform their SPS measures to international standards under Article 3.2; or

- impose SPS measures resulting in a higher level of protection than would be achieved by the relevant international standard in terms of Article 3.3.

In EC - Hormones the Appellate Body confirmed that these are equally available options and there is no rule-exception relationship between them. ${ }^{99}$ Thus a Member is not penalised for choosing the Article 3.3 alternative. The three options will now be examined in more detail.

The first option is set out in Article 3.1 of the SPS Agreement. When Members choose this option, Article 3.1 obliges Members to base their SPS measures on international standards where they exist, except as provided for in Article 3.3. ${ }^{100}$ The 'international standards' to which Article 3.1 refers are standards set by international organisations, such as the Codex Alimentarius Commission with respect to food safety, the International Office of Epizootics

97 Article 3 refers to 'international standards, guidelines or recommendations'. For reasons of convenience, the term 'international standards' will be used in this paper to refer to 'international standards, guidelines or recommendations'.

98 Appellate Body Report, EC - Hormones para. 177.

99 Ibid., para. 104.

100 See above, footnote 97 on the use of the term 'international standard'. 
for animal health, and the Secretariat of the International Plant Protection Convention with respect to plant health. ${ }^{101}$

Where a relevant international standard exists, Members must, according to Article 3.1, 'base' their SPS measures thereon. With respect to the meaning of the 'based on' requirement, the Appellate Body made the following observations in EC - Hormones:

... To read Article 3.1 as requiring Members to harmonize their SPS measures by conforming those measures with international standards, guidelines and recommendations, in the here and now, is, in effect, to vest such international standards, guidelines and recommendations (which are by the terms of the Codex recommendatory in form and nature) with obligatory force and effect. The Panel's interpretation of Article 3.1 would, in other words, transform those standards, guidelines and recommendations into binding norms. But, as already noted, the SPS Agreement itself sets out no indication of any intent on the part of the Members to do so. We cannot lightly assume that sovereign states intended to impose upon themselves the more onerous, rather than the less burdensome, obligation by mandating conformity or compliance with such standards, guidelines and recommendations. To sustain such an assumption and to warrant such a far-reaching interpretation, treaty language far more specific and compelling than that found in Article 3 of the SPS Agreement would be necessary. ${ }^{102}$

Thus, the non-binding standards set by the international standard-setting organisations do not become binding through the operation of the SPS Agreement. According to the Appellate Body in EC - Hormones a measure that is 'based on' an international standard is one that 'stands' or 'is founded', or 'built' upon or 'supported' by the international standard. An SPS measure which is 'based on' an international standard need not 'conform to' that standard, since not all of the elements of that standard may be incorporated into the measure. $^{103}$

The consequences of choosing the option under Article 3.1, by 'basing' an SPS measure on an international standard were set out by the Appellate Body in EC - Hormones as follows:

101 See Annex A, paragraph 3(a), (b) and (c) of the SPS Agreement. For matters not covered by the three mentioned organisations, international standards within the meaning of Article 3 of the SPS Agreement may also be standards set by other relevant international organizations open for membership to all WTO Members, as identified by the SPS Committee (see Annex A, paragraph 3(d) of the SPS Agreement). Pursuant to Article 3.4 of the SPS Agreement, Members have an obligation to participate in the work of the Codex Alimentarius Commission and the other organisations to the extent that their resources permit and to promote the development and periodic review of international standards.

102 Appellate Body Report, EC - Hormones, para. 165.

103 Ibid., para. 163. 
... The Member imposing this measure does not benefit from the presumption of consistency set up in Article 3.2; but, as earlier observed, the Member is not penalized by exemption of a complaining Member from the normal burden of showing a prima facie case of inconsistency with Article 3.1 or any other relevant article of the SPS Agreement or of the GATT 1994. ${ }^{104}$

The second option available to Members under Article 3.2 is to 'conform' their SPS measures to the relevant international standard. To 'conform to' is obviously more demanding than to 'base' on. In EC - Hormones the Appellate Body interpreted this requirement as follows:

... Such a measure would embody the international standard completely and, for practical purposes, converts it into a municipal standard. ${ }^{105}$

Article 3.2 provides that SPS measures which 'conform to' international standards are presumed to be consistent with the SPS Agreement and the GATT 1994. ${ }^{106}$ The implications of this presumption were addressed by the Appellate Body as follows:

The presumption of consistency with relevant provisions of the SPS Agreement that arises under Article 3.2 in respect of measures that conform to international standards may well be an incentive for Members so to conform their SPS measures with such standards. It is clear, however, that a decision of a Member not to conform a particular measure with an international standard does not authorize imposition of a special or generalized burden of proof upon that Member, which may, more often than not, amount to a penalty. ${ }^{107}$

Clearly, therefore, the burden of proof relies on the complaining party to demonstrate a violation of the SPS Agreement, under both the Article 3.1 option and the Article 3.2 option. However, the burden is heavier in the latter case as the complaining party has to overcome the presumption of consistency in Article 3.2. This provides an incentive for Members to conform their measures to international standards, thereby making their measures less vulnerable to challenges under the SPS Agreement and the GATT.

The third option that Members may choose, with respect to international standards, is to deviate from the international standard by choosing a measure resulting in a higher level of protection than that achieved by the international standard. This option, provided for in Article 3.3 of the SPS Agreement is important as it reflects the recognition of Members' right

\footnotetext{
104 Ibid., para. 171.

105 Ibid., para. 170.

106 This presumption was held to be rebuttable by the Appellate Body in EC - Hormones (See Ibid.).

107 Ibid., para. 102.
} 
to choose the level of protection they deem appropriate in their territories. In respect of this option, the Appellate Body in EC - Hormones held:

The right of a Member to establish its own level of sanitary protection under Article 3.3 of the SPS Agreement is an autonomous right and not an 'exception' from a 'general obligation' under Article 3.1. ${ }^{108}$

This right to choose measures that deviate from international standards is not an 'absolute or unqualified right', as confirmed by the Appellate Body in EC - Hormones. ${ }^{109}$ Two alternative conditions are laid down in Article 3.3, namely that:

- either there must be a scientific justification for the SPS measure (defined in a footnote as a scientific examination and evaluation in accordance with the rules of the SPS Agreement);

- or the measure must be a result of the level of protection chosen by the Member in accordance with Articles 5.1 through 5.8.

The difference between these two conditions is not clear and the Appellate Body noted, in $E C$ - Hormones, that 'Article 3.3 is evidently not a model of clarity in drafting and communication. ${ }^{110}$ What is clear, however, is that in both cases a risk assessment in terms of Article 5.1 is required. In this respect, the Appellate Body in EC - Hormones held as follows:

It is true that situation (a) does not speak of Articles 5.1 through 5.8. Nevertheless, two points need to be noted. First, the last sentence of Article 3.3 requires that "all measures which result in a [higher] level of ... protection", that is to say, measures falling within situation (a) as well as those falling within situation (b), be "not inconsistent with any other provision of [the SPS] Agreement". "Any other provision of this Agreement" textually includes Article 5. Secondly, the footnote to Article 3.3, while attached to the end of the first sentence, defines "scientific justification" as an "examination and evaluation of available scientific information in conformity with relevant provisions of this Agreement...”. This examination and evaluation would appear to partake of the nature of the risk assessment required in Article 5.1 and defined in paragraph 4 of Annex A of the SPS Agreement.

On balance, we agree with the Panel's finding that although the European Communities has established for itself a level of protection higher, or more exacting, than the level of protection implied in the relevant Codex standards, guidelines or recommendations, the European Communities was bound to comply with the requirements established in Article 5.1. We are not unaware that this finding tends to suggest that the distinction made in Article 3.3 between two situations may have very limited effects and may, to that extent, be more apparent than real. Its involved and layered language actually leaves us with no choice. ${ }^{111}$

\footnotetext{
108 Ibid., 172.

109 Ibid., para. 172.

110 Ibid., para. 175.

111 Ibid., paras. 175-176.
} 
The result of this ruling is that a Member who claims scientific justification for its deviation from the relevant international standard must base its claim on a proper risk assessment in the same way as a Member which claims its deviation is a result of the higher level of protection that it has chosen. The Appellate Body, in EC - Hormones, noted in this respect its belief that:

... compliance with Article 5.1 was intended as a countervailing factor in respect of the right of Members to set their appropriate level of protection ${ }^{112}$

\subsection{Risk Analysis Obligations}

The national regulatory process by means of which SPS measures are imposed typically involves risk analysis. For the purposes of the SPS Agreement, two elements of risk analysis are relevant, namely risk assessment and risk management. The term 'risk assessment' refers to the scientific process of identifying the existence of a risk and establishing the likelihood that the risk may actually materialise according to the measures that could be applied to address the risk. 'Risk management', by contrast, is the policy-based process of determining the level of protection a country wants to ensure in its territory and choosing the measure that will be used to achieve that level of protection. In risk management decision-making, not only are the scientific results of the risk assessment taken into account but also societal value considerations such as consumer preferences, industry interests, relative costs, etc. The distinction between these two elements of the risk analysis process is not absolute and nonscientific considerations do play some part in risk assessment. However, the distinction is a useful tool in enhancing the understanding of the regulatory process.

The risk assessment/risk management distinction is implicitly taken into account in those disciplines of the SPS Agreement that relate to the risk analysis process contained in Article 5. Articles 5.1 to 5.3 set strict scientific disciplines for risk assessments on which SPS measures must be based, whereas a Member's choice of an appropriate level of protection an aspect of risk management - is largely respected by the provisions of Articles 5.4 to 5.5. The choice of a measure to achieve this level of protection, another aspect of risk management, is subject to trade-related rather than scientific disciplines in Articles 5.3 and 5.6.

112 Ibid., para. 177. 
As noted by the Appellate Body in EC - Hormones, the SPS Agreement does not expressly use the term 'risk management'. ${ }^{113}$ However, it is undeniable that the SPS Agreement deals in different ways with Members' obligations with regard to risk assessment and those obligations applicable to what is commonly known as risk management.

\subsubsection{Risk assessment}

Article 5.1 of the SPS Agreement states:

Members shall ensure that their sanitary or phytosanitary measures are based on an assessment, as appropriate to the circumstances, of the risks to human, animal or plant life or health, taking into account risk assessment techniques developed by the relevant international organizations.

Article 5.1 thus obliges Members to base their SPS measures on a risk assessment as deemed appropriate to the circumstances. A 'risk assessment' is defined in paragraph 4 of Annex A of the SPS Agreement as follows:

The evaluation of the likelihood of entry, establishment or spread of a pest or disease within the territory of an importing Member according to the sanitary or phytosanitary measures which might be applied, and of the associated potential biological and economic consequences; or the evaluation of the potential for adverse effects on human or animal health arising from the presence of additives, contaminants, toxins or disease-causing organisms in food, beverages or feedstuffs.

There are thus two types of risk assessment, each with different requirements. The type of risk assessment required in a given case will depend on the type of SPS measure at issue. The first type of risk assessment is applicable to SPS measures aimed at risks from pests or diseases; the second to SPS measures aimed at food-borne risks. ${ }^{114}$ The former involves not only an assessment of the risk of entry, establishment or spread of a pest or disease but also an assessment of the risk of the associated potential biological and economic consequences. ${ }^{115}$ Such a risk assessment must:

- identify the pests/diseases whose entry, establishment or spread a Member wants to prevent, as well as the potential biological and economic consequences associated with the entry, establishment or spread of such pests/diseases;

\footnotetext{
113 Ibid., para. 181.

114 The requirements of the second type are less strict as human health issues are more likely to be at stake in such cases.

115 Panel Report, Australia - Salmon para. 8.72.
} 
- evaluate the likelihood of entry, establishment or spread of these pests/diseases and the associated biological and economic consequences; and

- evaluate the likelihood of entry, establishment or spread of these diseases according to the SPS measures that might be applied. ${ }^{116}$

There are two requirements for the second type of risk assessment, which applies to foodborne risks, namely that the risk assessment must:

- identify the adverse effects on human or animal health (if any) arising from the additive, contaminant, toxin or disease-causing organism in food/beverages/feedstuffs at issue; and

- if such adverse health effects exist, evaluate the potential of occurrence of these effects. $^{117}$

Note certain important differences between these two types of risk assessment. First, the requirements for the second type of risk assessment do not include an evaluation of associated biological and economic consequences. This is supported in Article 5.3, which specifies certain economic factors that Members must take into account in 1) assessing risks to animal and plant life or health (not to human life or health); and 2) in choosing an SPS measure.

Thus, economic considerations form an inherent part of a risk assessment in terms of the SPS Agreement. However, the exclusion of risk assessments with regard to human health risks from the provisions of this article indicates that Members are not obliged to take economic factors into account in making decisions regarding the protection of human health, most likely because the drafters of the SPS Agreement did not think it reasonable to require Members to weigh up economic considerations and associated biological risks in such circumstances.

Second, while the first type of risk assessment requires an evaluation of the 'likelihood' that the risk might materialise, the second type requires only an evaluation of the 'potential' for adverse effects. Neither 'likelihood' nor 'potential' imply that the risk assessed must be

116 This three-pronged test was set out by the Panel and endorsed by the Appellate Body in Appellate Body Report, Australia - Salmon, para. 121. This test was confirmed in Appellate Body Report, Japan Agricultural Products, para. 113 and used again in Panel Report, Australia - Salmon (Article 21.5), para. 7.41 .

117 These requirements are generalised on the basis of the findings of the Panel in EC - Hormones (Panel Report, EC - Hormones (Canada), para. 8.101; Panel Report, EC - Hormones (US), para. 8.98) as modified by the Appellate Body (Appellate Body Report, EC - Hormones, para. 184-186). 
quantified (i.e., expressed numerically) or that a certain threshold level of risk be shown. Instead, the risk may be expressed either quantitatively or qualitatively. ${ }^{118}$ However, the word 'likelihood' used with regard to the first type of risk assessment was held to imply a higher degree of potentiality than the word 'potential' used with regard to the second type. ${ }^{119}$ This difference in wording was emphasised by the Appellate Body in Australia - Salmon. ${ }^{120}$ The Appellate Body observed:

We note that the first definition in paragraph 4 of Annex A speaks about the evaluation of "likelihood". In our report in European Communities - Hormones, we referred to the dictionary meaning of "probability" as "degrees of likelihood" and "a thing that is judged likely to be true", for the purpose of distinguishing the terms "potential" and "probability". For the present purpose, we refer in the same manner to the ordinary meaning of "likelihood", and we consider that it has the same meaning as "probability". On this basis, as well as on the basis of the definition of "risk" and "risk assessment" developed by the Office international des épizooties ('OIE') and the OIE Guidelines for Risk Assessment, we maintain that for a risk assessment to fall within the meaning of Article 5.1 and the first definition in paragraph 4 of Annex A, it is not sufficient that a risk assessment conclude that there is a possibility of entry, establishment or spread of diseases and associated biological and economic consequences. A proper risk assessment of this type must evaluate the "likelihood", i.e., the "probability", of entry, establishment or spread of diseases and associated biological and economic consequences as well as the "likelihood", i.e., "probability", of entry, establishment or spread of diseases according to the SPS measures which might be applied. ${ }^{121}$

Third, a risk assessment concerning phytosanitary measures must evaluate the likelihood of the risk's occurance according to the SPS measures "which might be applied". In Japan Apples, the Appellate Body agreed with the Panel that a risk assessment under this definition may not be limited to an examination of the measure already in place but that other possible alternatives must also be evaluated. ${ }^{122}$ The Appellate Body emphasised that a risk assessment:

...[S]hould not be distorted by preconceived views on the nature and the content of the measure to be taken; nor should it develop into an exercise tailored to and carried out for the purpose of justifying decisions ex post facto. $^{123}$

118 With regard to the first definition of risk assessment, the Appellate Body agreed with the Panel that the evaluation of likelihood may be expressed quantitatively or qualitatively in Appellate Body Report, Australia - Salmon para. 124. In respect of the second definition, the Appellate Body noted that there is no basis for a quantitative requirement in Appellate Body Report, EC - Hormones para. 186.

119 Appellate Body Report, EC - Hormones para. 184.

120 Appellate Body Report, Australia - Salmon footnote 69.

121 Ibid., para. 123.

122 Panel Report, Japan-Apples, para. 8.283.

123 Appellate Body Report, Japan-Apples, para. 208. 
Therefore, it appears that the differences between the two types of risk assessment are intended to set less strict requirements for risk assessments where risks to human health are concerned, namely when dealing with food safety issues rather than when the risk relates to plant/animal pests or diseases.

Furthermore, some general observations can be made with respect to the requirements for risk assessments as identified in the case law. First, the Appellate Body has held that a risk assessment must show proof of an actual risk, not just a theoretical uncertainty. ${ }^{124}$ Second, the Appellate Body has recognised that a risk assessment may go beyond controlled laboratory conditions and take account of the actual potential for adverse effects in the 'real world where people live and work and die'. ${ }^{125}$ Third, the risk assessment must be specific to the particular type of risk at issue in the case and not merely show a general risk of harm. ${ }^{126}$ Fourth, Article 5.1 does not oblige Members to carry out their own risk assessments. Instead they may rely on risk assessments carried out by other Members or an international organisation. $^{127}$

Although the SPS Agreement does not lay down any methodology of risk assessment to be followed by Members, it does specify certain factors that Members must take into account in their risk assessments. Article 5.2 lists certain scientific and technical factors that Members must consider when assessing risks. These are:

[A]vailable scientific evidence; relevant processes and production methods; relevant inspection, sampling and testing methods; prevalence of specific diseases or pests; existence of pest- or disease-free areas; relevant ecological and environmental conditions; and quarantine or other treatment.

From this list it is clear that a risk assessment for the purposes of the SPS Agreement is not purely scientific (in the sense of laboratory science) but includes a consideration of realworld factors that affect risk such as climatic conditions, control mechanisms etc. This was further supported in EC - Hormones by the Appellate Body's rejection of the Panel's finding that the risks relating to control and detection of failure to observe good veterinary practices

\footnotetext{
124 Appellate Body Report, EC - Hormones para.186.

125 Ibid., para. 187. See also below, Sec. 3.4.1.

126 Ibid., para.200. In Japan - Apples the Appellate Body agreed with the Panel that the risk assessment must be specific not only to the harm at issue but also to the agent that causes the harm (in that case the product that transmitted the disease). Appellate Body Report, Japan - Apples, para. 204.

127 Ibid., para. 190.
} 
must be excluded from risk assessments as they are non-scientific and thus outside the scope of Article 5.2. The Appellate Body held:

The listing in Article 5.2 begins with "available scientific evidence"; this, however, is only the beginning. We note in this connection that the Panel states that, for purposes of the EC measures in dispute, a risk assessment required by Article 5.1 is "a scientific process aimed at establishing the scientific basis for the sanitary measure a Member intends to take". To the extent that the Panel intended to refer to a process characterized by systematic, disciplined and objective enquiry and analysis, that is, a mode of studying and sorting out facts and opinions, the Panel's statement is unexceptionable. However, to the extent that the Panel purports to exclude from the scope of a risk assessment in the sense of Article 5.1, all matters not susceptible of quantitative analysis by the empirical or experimental laboratory methods commonly associated with the physical sciences, we believe that the Panel is in error. Some of the kinds of factors listed in Article 5.2 such as "relevant processes and production methods" and "relevant inspection, sampling and testing methods"' are not necessarily or wholly susceptible of investigation according to laboratory methods of, for example, biochemistry or pharmacology. Furthermore, there is nothing to indicate that the listing of factors that may be taken into account in a risk assessment of Article 5.2 was intended to be a closed list. It is essential to bear in mind that the risk that is to be evaluated in a risk assessment under Article 5.1 is not only risk ascertainable in a science laboratory operating under strictly controlled conditions, but also risk in human societies as they actually exist, in other words, the actual potential for adverse effects on human health in the real world where people live and work and die. ${ }^{128}$

However, the Appellate Body qualified its finding by noting that it does not imply that risks related to problems of control always need to be evaluated in a risk assessment. The necessity to evaluate such risks depends on the circumstances of each case. ${ }^{129}$

As noted above, Article 5.1 of the SPS Agreement requires that SPS measures are 'based on' a risk assessment. The meaning of 'based on' was clarified by the Appellate Body in EC Hormones. The Appellate Body in that case rejected the Panel's finding that the risk assessment must be shown to have been 'taken into account' by the Member in imposing the SPS measure and that the SPS measure must 'conform' to the risk assessment. ${ }^{130}$ Instead, the Appellate Body held that for an SPS measure to be 'based on' a risk assessment, there must be a 'rational relationship' between the measure and the risk assessment and the risk assessment must 'reasonably support' the measure. ${ }^{131}$

\footnotetext{
${ }^{128}$ Ibid., para.187.

129 Ibid., para. 206.

130 Ibid., paras 189 and 193.

131 Ibid., para. 193.
} 
The Appellate Body also ruled that it is possible for an SPS measure to be based on divergent views rather than mainstream scientific opinion. In this respect, the Appellate Body stated in EC-Hormones:

We do not believe that a risk assessment has to come to a monolithic conclusion that coincides with the scientific conclusion or view implicit in the SPS measure. The risk assessment could set out both the prevailing view representing the "mainstream" of scientific opinion, as well as the opinions of scientists taking a divergent view. Article 5.1 does not require that the risk assessment must necessarily embody only the view of a majority of the relevant scientific community. ... In most cases, responsible and representative governments tend to base their legislative and administrative measures on "mainstream" scientific opinion. In other cases, equally responsible and representative governments may act in good faith on the basis of what, at a given time, may be a divergent opinion coming from qualified and respected sources. By itself, this does not necessarily signal the absence of a reasonable relationship between the SPS measure and the risk assessment, especially where the risk involved is life-threatening in character and is perceived to constitute a clear and imminent threat to public health and safety. Determination of the presence or absence of that relationship can only be done on a case-tocase basis, after account is taken of all considerations rationally bearing upon the issue of potential adverse health effects. ${ }^{132}$

In Japan-Apples, the Panel examined what is meant by the requirement of Article 5.1 that measure must be based on a risk assessment "as appropriate to the circumstances". It held that this factor, together with the consideration of the risk assessment techniques developed by the relevant international organizations, pervades the entire risk assessment as defined in Annex $\mathrm{A}$ and is therefore relevant to the evaluation of the risk assessment as a whole. It therefore addressed this first, before looking at other requirements for a risk assessment. ${ }^{133}$ The Panel first found, rather obviously, that as Japan's measure was a phytosanitary measure, it must focus on risks related to plant life and health. ${ }^{134}$ It then noted that the term "as appropriate to the circumstances" has been interpreted, in Australia-Salmon, to provide some flexibility for risk assessments, on a case-by-case basis, including consideration of countryspecific situations. It therefore found that Japan's fire blight-free status and its climatic conditions, which were favorable to the spread of fire blight, were relevant "circumstances" to be taken into account in Japan's risk assessment, and noted that they related to some of the factors required to be considered under Article 5.2. ${ }^{135}$

\footnotetext{
132 Ibid., para 194.

${ }^{133}$ Panel Report, Japan-Measures, para. 8.237.

${ }^{134}$ Id., 8.238 .

${ }^{135} I d$., 8.240 and note 372 .
} 
Finally, Article 5.1 further requires that a risk assessment take into account the risk assessment techniques which are developed by the relevant international organizations. It can be assumed that these organizations are those referred to in the definition of "international standards, guidelines and recommendations" in Annex A, paragraph 3, primarily the CAC, OIE and IPPC, since these organizations are the most relevant for SPS matters. In AustraliaSalmon, as noted above, the Panel took account of the risk assessment techniques developed by the OIE as part of its consideration of what is covered by the term "as appropriate to the circumstances". ${ }^{136}$ In Japan-Apples, however, the Panel examined this issue separately, as one of the two factors which pervade the evaluation of a risk assessment. After noting that Article 5.1 merely requires that these risk assessment techniques be "taken into account", rather than that a risk assessment be "based on" or "in conformity with" them, the Panel found that:

...[S]uch techniques should be considered relevant, but that a failure to respect each and every aspect of them would not necessarily, per se, signal that the risk assessment on which the measure is based is not in conformity with the requirements of Article 5.1. Nonetheless, reference to these risk assessment techniques can provide very useful guidance as to whether the risk assessment at issue constitutes a proper risk assessment within the meaning of Article 5.1. ${ }^{137}$

It is thus clear that the risk assessment techniques developed by the relevant international organizations, while useful, are not determinative to the determination whether a risk assessment complies with Article 5.1.

\subsubsection{Risk management}

Risk management, as explained above, entails policy decision-making regarding the level of protection that a country wants to secure in its territory and the measure it will use to achieve this level of protection. These choices are 'based on' both scientific evidence and societal value judgments. The SPS Agreement gives national regulators substantial latitude in making

\footnotetext{
${ }^{136}$ Panel Report, Australia-Measures Affecting the Importation of Salmon, para. 8.71.

137 Id. para. 8.241. In this context, the Panel examined two relevant standards set by the International Plant Protection Convention, ISPM 2 on Guidelines for Pest Risk Analysis, and ISPM 11 on Pest Risk Analysis for Quarantine Pests. The parties agreed that both instruments build upon the same framework, thus the Panel focused on the key issue of whether Japan's risk assessment sufficiently identified and assessed the possible pathways for the introduction and spread of fire blight through apple fruit and the likelihood for their being realised, as required by both instruments. Id., If 8.244.
} 
risk management decisions, but there are certain non-scientific disciplines in place to ensure that the adverse trade effects of these decisions are limited as much as possible.

Risk management entails, in the first place, the decision on the 'appropriate level of protection', defined in paragraph 5 of Annex A of the SPS Agreement as:

The level of protection deemed appropriate by the Member establishing a sanitary or phytosanitary measure to protect human, animal or plant life or health within its territory. [Emphasis added]

Thus, there is a clear recognition that it is the prerogative of the Member imposing the SPS measure to choose the level of protection of human, animal or plant life or health it will enforce in its territory. The SPS Agreement does not oblige Members to lower their level of protection, even where this would be most trade-efficient. Once the existence of a risk has been established by means of risk assessment, a Member is free to choose even a zero-risk level of protection. ${ }^{138}$

Two provisions in the SPS Agreement deal with the choice of an appropriate level of protection. First, Article 5.4 provides that Members should take into account the objective of minimising negative trade effects when choosing their level of protection. The word 'should' indicates that this provision is only hortative, containing no binding obligation. Obliging Members to choose the least trade restrictive level of protection would go against the underlying principle of the SPS Agreement that it is the prerogative of the Member to determine the level of protection it deems appropriate in its territory.

The second discipline with regard to the appropriate level of protection is contained in Article 5.5, which provides in relevant part:

With the objective of achieving consistency in the application of the concept of appropriate level of sanitary or phytosanitary protection against risks to human life or health, or to animal and plant life or health, each Member shall avoid arbitrary or unjustifiable distinctions in the levels it considers to be appropriate in different situations, if such distinctions result in discrimination or a disguised restriction on international trade.

Two elements of the Article 5.5 discipline can be distinguished, namely:

138 Appellate Body Report, Australia - Salmon para. 125. 
- the goal (for the future) of achieving consistency in the application of the 'concept' of 'appropriate level of sanitary or phytosanitary protection'; ${ }^{139}$ and

- the legal obligation to avoid arbitrary or unjustifiable distinctions in the levels of protection deemed appropriate in different situations, if these distinctions lead to discrimination or disguised restrictions on trade.

In EC - Hormones, the Appellate Body recognised that countries establish their levels of protection $a d$ hoc as risks arise, thus absolute consistency in levels of protection is not required (nor realistic). Only arbitrary or unjustifiable distinctions in levels of protection must be avoided. ${ }^{140}$

Three cumulative requirements must be met before a violation of Article 5.5 exists:

- the Member has set different levels of protection 'in different situations';

- the levels of protection show 'arbitrary or unjustifiable' differences in their treatment of different situations; and

- these arbitrary or unjustifiable differences lead to 'discrimination or disguised restrictions' on trade. ${ }^{141}$

Clearly not all health risks can be treated the same. Thus, according to the Appellate Body in $E C$ - Hormones, the 'different' situations compared in the first element of the test under Article 5.5 must be comparable, that is, they must have some common element or elements. ${ }^{142}$ For example, a common element would be the fact that a spread of the same disease is at issue, or that identical biological or economic consequences could result. ${ }^{143} \mathrm{~A}$ difference in the levels of protection applied in the comparable situations must then be shown. In Australia - Salmon, the Panel held that the chosen level of protection is reflected in the SPS measure imposed, thus ensuring that a difference in the measures applied in the situations being compared would indicate a distinction in the level of protection. Although this particular finding was not appealed, ${ }^{144}$ it should be noted that in dealing with Article 5.6, the Appellate Body, in this case, held that nothing in the DSU or the SPS Agreement permits a panel or the Appellate Body to imply a Member's appropriate level of protection from the

\footnotetext{
${ }^{139}$ In EC - Hormones the Appellate Body agreed with the Panel that no legal obligation of consistency in levels of protection exists, but that consistency in levels of protection is only a goal for the future. (Appellate Body Report, EC - Hormones para. 213).

140 Ibid., para. 213.

141 Ibid., para. 214, reiterated in Appellate Body Report, Australia - Salmon para. 140.

142 Appellate Body Report, EC - Hormones para. 217.

143 Appellate Body Report, Australia - Salmon para. 146.

144 Ibid., fn. 106.
} 
measure it imposes. ${ }^{145}$ Only if a Member does not express its chosen level of protection or does so too vaguely, can its level of protection be inferred from the measure it applies.

The second element of the test under Article 5.5 requires that to constitute a violation the differences in levels of protection be 'arbitrary or unjustifiable'. To determine whether this requirement is met, panels and the Appellate Body examine whether reasons exist to justify the differences in levels of protection. In the case law so far, they have examined:

- whether different levels of risk are at issue in the different situations compared; ${ }^{146}$

- whether the difficulty of controlling the risk differs in each case, ${ }^{147}$ or

- whether the degree of government intervention necessary to achieve the same level of protection differs in each situation. ${ }^{148}$

The third and most important element of the test under Article 5.5, according to the Appellate Body in $E C$-Hormones, is the requirement that the arbitrary or unjustifiable distinctions in levels of protection lead to 'discrimination or disguised restrictions on trade'. ${ }^{149}$ Whether this requirement is met can be determined by means of three 'warning signals' identified in the case law which are not conclusive in their own right but taken together and with other factors may support the finding that the third element of the test under Article 5.5 is met. ${ }^{150}$ This will depend on the circumstances of each case. The warning signals are:

- the arbitrary character of the differences in the levels of protection (i.e., that the second element of Article 5.5 is met);

- the existence of rather substantial differences in the levels of protection; and

- the absence of scientific justification (based on earlier findings of a violation of Articles 2.2 and 5.1) which indicates that the measure is a disguised trade restriction.

In June 2000, the SPS Committee drew up guidelines for the implementation of Article 5.5. ${ }^{151}$ The guidelines, resulting from a series of consultations in the SPS Committee, reflect the clarifications emerging from the case law on Article 5.5, including the use of the three 'warning signals'.

\footnotetext{
145 This issue is discussed further in the analysis of Article 5.6 below.

146 Appellate Body Report, Australia - Salmon para. 158.

147 Appellate Body Report, EC - Hormones para. 221-225.

148 Ibid., para. 221.

149 Ibid., para. 240.

150 Panel Report, Australia - Salmon paras 8.149-8.151, as approved by the Appellate Body (Appellate Body Report, AustraliaSalmon paras 162, 164 and 166). The first two warning signals were also relied upon in Appellate Body Report EC-Hormones paras. 215 and 240.

151 These guidelines are contained in document G/SPS/15. They are not binding but intended to assist officials in the application of Article 5.5.
} 
In addition to the disciplines regarding the choice of an appropriate level of protection, the SPS Agreement contains rules regarding the choice of an SPS measure to achieve the chosen level of protection. The first such rule is Article 5.3, which, as discussed above, lists certain economic criteria that Members must consider in their risk assessments and their choice of SPS measures. The second discipline, on the choice of measure, is contained in Article 5.6, which provides:

Without prejudice to paragraph 2 of Article 3, when establishing or maintaining sanitary or phytosanitary measures to achieve the appropriate level of sanitary or phytosanitary protection, Members shall ensure that such measures are not more trade-restrictive than required to achieve their appropriate level of sanitary or phytosanitary protection, taking into account technical and economic feasibility.

In footnote to Article 5.6, it is stated:

For purposes of paragraph 6 of Article 5, a measure is not more trade-restrictive than required unless there is another measure, reasonably available taking into account technical and economic feasibility, that achieves the appropriate level of sanitary or phytosanitary protection and is significantly less restrictive to trade.

On the basis of this footnote, the Panel in Australia - Salmon identified a three-pronged test which was later upheld by the Appellate Body, namely that an SPS measure is more trade restrictive than required only if there is an alternative SPS measure which:

- is reasonably available, taking into account technical and economic feasibility;

- achieves the Member's appropriate level of protection; and

- is significantly less trade restrictive than the contested measure. ${ }^{152}$

Since these requirements are cumulative, all three must be met in order to prove a violation of Article 5.6. ${ }^{153}$

To determine whether the first element of this test is met, a panel will look at the facts of the case, including the characteristics of the SPS measure actually applied, as well as the alternative measures considered in the risk assessment, in order to determine which of the latter measures is a feasible alternative. ${ }^{154}$

${ }_{152}$ Panel Report, Australia - Salmon, para. 95 and Appellate Body Report, Australia - Salmon, para. 194.

${ }^{153}$ Appellate Body Report, Australia - Salmon, para. 194, reiterated in Appellate Body Report, Japan Agricultural Products, para. 95.

${ }^{154}$ Panel Report, Australia - Salmon, para. 8.171 and Panel Report, Australia - Salmon (Article 21.5), paras. 7.146-7.149. 
To determine whether the second element of this test is met, it is necessary to establish what the appropriate level of protection is for the importing Member. As mentioned above the Appellate Body rejected the Panel's finding that the appropriate level of protection can be implied from the level of protection that is afforded by the SPS measure imposed. The Appellate Body emphasised that the choice of a level of protection is the prerogative of the Member concerned. ${ }^{155}$ Further, it held:

The "appropriate level of protection" established by a Member and the "SPS measure" have to be clearly distinguished. They are not one and the same thing. The first is an objective, the second is an instrument chosen to attain or implement that objective.

It can be deduced from the provisions of the SPS Agreement that the determination by a Member of the "appropriate level of protection" logically precedes the establishment or decision on maintenance of an "SPS measure". ${ }^{156}$

There are, however, cases where Members do not expressly determine their appropriate level of protection, or do so with insufficient clarity so that it becomes impossible to apply Article 5.6 (and Article 5.5). The Appellate Body in Australia - Salmon recognised this and thus read an implicit obligation on Members to determine their appropriate levels of protection into paragraph 3 of Annex B and Articles 4.1, 5.4 and 5.6. It held as follows:

... we believe that in cases where a Member does not determine its appropriate level of protection, or does so with insufficient precision, the appropriate level of protection may be established by panels on the basis of the level of protection reflected in the SPS measure actually applied. Otherwise, a Member's failure to comply with the implicit obligation to determine its appropriate level of protection - with sufficient precision - would allow it to escape from its obligations under this Agreement and, in particular, its obligations under Articles 5.5 and $5.6 .^{157}$

Thus, where Members do not comply with their implicit obligation to determine their appropriate level of protection, their appropriate level of protection may be deduced from the SPS measure actually applied.

The third element of the test under Article 5.6 was examined by both the Panel and the Article 21.5 Panel in Australia - Salmon and by the Panel in Japan - Agricultural Products. ${ }^{158}$ It appears from these cases that the issue relates to whether market access will

\footnotetext{
155 Appellate Body Report, Australia - Salmon, para. 199.

156 Ibid., paras 200-201.

157 Ibid., paras 205-207.

158 Panel Report, Australia - Salmon, para. 8.182; Panel Report, Australia - Salmon (21.5), paras. 7.150-7.153; Panel Report, Japan - Agricultural Products, paras. 8.79, 8.89, 8.95-8.96 and 8.103-8.10.
} 
be substantially improved were an alternative measure imposed. This is particularly evident in the Panel's statement in Australia - Salmon preferring restrictions over exclusion:

All four alternative options outlined above would allow imports of the salmon products further examined, albeit under specific conditions [...]. We consider that even imposing the most stringent of these specific conditions would still be significantly less restrictive to trade than an outright prohibition. ${ }^{159}$

\subsubsection{Provisional measures and the precautionary principle}

While the SPS Agreement requires that SPS measures are 'based on' science and uses science as the touchstone against which SPS measures will be judged, it is obvious that science does not have clear and unambiguous answers to all regulatory problems. Situations may arise where there is, in fact, insufficient scientific evidence regarding the existence and extent of the relevant risk but where governments consider they need to act promptly and take measures to avoid possible harm. Thus, governments act with precaution without waiting for the collection of sufficient scientific information and knowledge to conclusively assess the risks. This is commonly referred to as acting in accordance with the 'precautionary principle', or the 'precautionary approach'. Considerable differences of opinion exist between Members regarding the role that precaution plays in the regulatory process. However, it is undisputable that precaution is an inherent part of risk regulation, particularly in the area of health and environment. ${ }^{160}$ It is thus important to establish to what extent the SPS Agreement allows for precautionary measures.

In Article 5.7, the SPS Agreement provides for the possibility to take, under certain conditions, provisional SPS measures where scientific information is insufficient. Article 5.7 may be regarded as a particular formulation of the precautionary principle. It provides:

In cases where relevant scientific evidence is insufficient, a Member may provisionally adopt sanitary or phytosanitary measures on the basis of available pertinent information, including that from the relevant international organizations as well as from sanitary or phytosanitary measures applied by other Members. In such circumstances, Members shall seek to obtain the additional information necessary for a more objective

\footnotetext{
${ }^{159}$ Panel Report, Australia - Salmon, para. 8.182.

${ }^{160}$ It is disputed whether precaution should be taken into account in risk assessment or whether it only comes into play in risk management decisions. There is also a difference of opinion as to whether precaution has emerged as a 'principle' in international law, or whether it is a mere 'approach' followed by countries.
} 
assessment of risk and review the sanitary or phytosanitary measure accordingly within a reasonable period of time.

From this definition, four cumulative requirements for provisional measures were identified by the Panel and confirmed by the Appellate Body in Japan-Agricultural Products, namely that the measure must:

- be imposed in respect of a situation where relevant scientific information is insufficient;

- be adopted on the basis of available pertinent information;

- not be maintained unless the Member seeks to obtain the additional information necessary for a more objective assessment of risk; and

- be reviewed accordingly within a reasonable period of time. ${ }^{161}$

The Panel in Japan-Apples addressed the first requirement. It held that a situation where the existence of 'relevant scientific evidence is insufficient' cannot merely be implied from a finding that the measure is maintained 'without sufficient scientific evidence' under Article 2.2. ${ }^{162}$ It held:

... Article 5.7 refers to "relevant scientific evidence" which implies that the body of material that might be considered includes not only evidence supporting Japan's position, but also evidence supporting other views. ${ }^{163}$

Since a wealth of scientific evidence was submitted in that case by both the parties and the panel experts, the Panel found that it was undisputable that a large amount of relevant scientific evidence was available. It held:

The current "situation", where scientific studies as well as practical experience have accumulated for the past 200 years, is clearly not the type of situation Article 5.7 was intended to address. Article 5.7 was obviously designed to be invoked in situations where little, or no, reliable evidence was available on the subject matter at issue $\ldots{ }^{164}$

On appeal, Japan challenged the Panel's finding that Article 5.7 is intended only to address situations where little, or no, reliable evidence was available on the subject matter at issue. According to Japan such an interpretation would not provide for situations of "unresolved

161 Panel Report, Japan - Agricultural Products, para. 8.54; and Appellate Body Report, Japan Agricultural Products, para. 89.

162 Panel Report, Japan - Apples, para. 8.215.

163 Ibid., para. 8.216.

164 Ibid., para. 8.215 
uncertainty". According to Japan, Article 5.7 covers not only situations of "new uncertainty" (where a new risk is identified) but also "unresolved uncertainty" (where considerable scientific evidence exists on the risk but uncertainty still remains). The Appellate Body, however, upheld the Panel's finding, pointing out that Article 5.7:

...is triggered not by the existence of scientific uncertainty, but rather by the insufficiency of scientific evidence. ${ }^{165}$

Moreover, it noted that the Panel's finding referred to the availability of reliable evidence, and thus did not exclude cases:

...where the available evidence is more than minimal in quantity, but has not led to reliable or conclusive results. ${ }^{166}$

In addition, in its discussion of the first element of Article 5.7, the Appellate Body identified a contextual link between the first requirement of Article 5.7 and the obligation to perform a risk assessment in Article 5.1. ${ }^{167}$ Thus, relevant scientific evidence will be insufficient for purposes of Article 5.7 if it:

...does not allow, in qualitative or quantitative terms, the performance of an adequate assessment of risks as required under Article 5.1. ${ }^{168}$

According to the Appellate Body, the factual findings of the Panel showed that the scientific evidence available did permit the performance of a risk assessment under Article 5.1 and the relevant scientific evidence was thus not insufficient within the meaning of Article 5.7.

This analysis of the first requirement of Article 5.7 is groundbreaking. It clarifies the role of Article 5.7, establishing that it is there to address situations where there is a true lack of sufficient scientific evidence regarding the risk at issue, either due to the small amount of evidence on new risks, or due to the fact that accumulated evidence is inconclusive or unreliable. In either case, the insufficiency of the evidence must be such as to make the an

\footnotetext{
165 Appellate Body Report, Japan - Apples, para. 184.

166 Appellate Body Report, Japan-Apples, para. 185.

167 The Appellate Body found these contextual elements in the following: first, the concepts of relevance and insufficiency in Article 5.7 imply a relationship between scientific evidence and something else; second, Article 5.1, obliging Members to base their measures on a risk assessment, contains a key discipline under Article 5 and informs the other provisions of Article 5; and third, Article 5.7 itself refers to 'a more objective assessment of risks'. Appellate Body Report, Japan - Apples, para. 179.

168 Appellate Body Report, Japan-Apples, para. 179.
} 
adequate risk assessment impossible. Thus Article 5.7 cannot be used to justify measures that are adopted in disregard of reliable scientific evidence.

There is no guidance in case law with respect to the second requirement of Article 5.7, that the measure be adopted on the basis of available pertinent information In Japan Agricultural Products and Japan - Apples, the Panels, exercising judicial economy, found it unnecessary to decide on this point. ${ }^{169}$

The third requirement of Article 5.7 was clarified by the Appellate Body in Japan Agricultural Products as follows:

Neither Article 5.7 nor any other provision of the SPS Agreement sets out explicit prerequisites regarding the additional information to be collected or a specific collection procedure. Furthermore, Article 5.7 does not specify what actual results must be achieved; the obligation is to 'seek to obtain' additional information. However, Article 5.7 states that the additional information is to be sought in order to allow the Member to conduct 'a more objective assessment of risk'. Therefore, the information sought must be germane to conducting such a risk assessment, i.e., the evaluation of the likelihood of entry, establishment or spread of, in casu, a pest, according to the SPS measures which might be applied. We note that the Panel found that the information collected by Japan does not 'examine the appropriateness' of the SPS measure at issue and does not address the core issue as to whether 'varietal characteristics cause a divergency in quarantine efficacy'. In the light of this finding, we agree with the Panel that Japan did not seek to obtain the additional information necessary for a more objective risk assessment. ${ }^{170}$

The fourth requirement of Article 5.7, namely to review the provisional SPS measure within a reasonable period of time, is a reflection of the time-limited nature of such measures under the SPS Agreement. However, as scientific uncertainty may sometimes persist for extended periods of time, artificially linking the requirement of review to a fixed time limit was avoided in the SPS Agreement, which instead refers to a 'reasonable period of time'. Thus, the possibility for a Member to maintain a measure as long as necessary for a scientific assessment to establish the presence or absence of a risk, is not compromised. In Japan Agricultural Products, the Appellate Body interpreted the requirement of review within a reasonable period of time as follows:

In our view, what constitutes a "reasonable period of time" has to be established on a case-by-case basis and depends on the specific circumstances of each case, including the difficulty of obtaining the additional information necessary for the review and the characteristics of the provisional SPS measure. In the present

\footnotetext{
169 Panel Report, Japan - Agricultural Products, para. 8.59; and Panel Report, Japan - Apples, para. 8.222.

170 Appellate Body Report, Japan - Agricultural Products, para. 92.
} 
case, the Panel found that collecting the necessary additional information would be relatively easy. Although the obligation "to review" the varietal testing requirement has only been in existence since 1 January 1995, we agree with the Panel that Japan has not reviewed its varietal testing requirement "within a reasonable period of time". ${ }^{171}$

The maintenance of provisional measures under Article 5.7, therefore, is dependent on the state of scientific knowledge that has a direct impact on the difficulty of obtaining the additional information necessary for review of the measure. This allows some flexibility with respect to the temporary nature of provisional SPS measures.

The question now arises whether Article 5.7 exhausts the relevance of the precautionary principle for the SPS Agreement. In EC-Hormones, the European Communities tried to rely on the precautionary principle as a general customary rule of international law, or at least a general principle of law applicable to the interpretation of the scientific disciplines in the SPS Agreement. The Appellate Body expressed doubts as to whether the precautionary principle had developed into a principle of general or customary international law as follows:

\footnotetext{
The status of the precautionary principle in international law continues to be the subject of debate among academics, law practitioners, regulators and judges. The precautionary principle is regarded by some as having crystallized into a general principle of customary international environmental law. Whether it has been widely accepted by Members as a principle of general or customary international law appears less than clear. We consider, however, that it is unnecessary, and probably imprudent, for the Appellate Body in this appeal to take a position on this important, but abstract, question. We note that the Panel itself did not make any definitive finding with regard to the status of the precautionary principle in international law and that the precautionary principle, at least outside the field of international environmental law, still awaits authoritative formulation. ${ }^{172}$
}

According to the Appellate Body, Article 5.7 does not exhaust the relevance of the precautionary principle. This principle is also reflected in the sixth paragraph of the Preamble to the SPS Agreement as well as in Article 3.3 of the SPS Agreement. Both these provisions deal with the right of Members to set their own level of protection, even if this level is higher than that reflected in international standards. It is doubtful whether this reflects the precautionary principle, however, since the choice of a particular level of protection, however high, presupposes that a risk has been established by means of a risk assessment.

\footnotetext{
171 Ibid., para. 93.

172 Appellate Body Report, EC - Hormones para. 123.
} 
The precautionary principle is relevant only where there is insufficient scientific information for the conduct of a proper risk assessment.

With respect to the relationship between the precautionary principle and the disciplines of the SPS Agreement, the Appellate Body held that the precautionary principle (presumably regardless of its status under international law) cannot override the explicit requirements of Articles 5.1 and 5.2 in cases of scientific uncertainty. It noted the following four considerations:

\footnotetext{
First, the principle has not been written into the SPS Agreement as a ground for justifying SPS measures that are otherwise inconsistent with the obligations of Members set out in particular provisions of that Agreement. Secondly, the precautionary principle indeed finds reflection in Article 5.7 of the SPS Agreement. (...) Thirdly, a panel charged with determining, for instance, whether "sufficient scientific evidence" exists to warrant the maintenance by a Member of a particular SPS measure may, of course, and should, bear in mind that responsible, representative governments commonly act from perspectives of prudence and precaution where risks of irreversible, e.g. life-terminating, damage to human health are concerned. Lastly, however, the precautionary principle does not, by itself, and without a clear textual directive to that effect, relieve a panel from the duty of applying the normal (i.e. customary international law) principles of treaty interpretation in reading the provisions of the SPS Agreement. ${ }^{173}$
}

The effect of this ruling is to limit the applicability of the precautionary principle under the SPS Agreement to the situation covered by Article 5.7. The precautionary principle can thus not be relied upon to add flexibility to the scientific disciplines of the SPS Agreement.

The Panel and Appellate Body's findings establish the fact that the precautionary principle, as embodied in Article 5.7, does not create a broad loophole in the scientific disciplines of the SPS Agreement through which protectionist measures can slip. Rather, it creates a limited exception for cases where there is a true lack of relevant and reliable scientific evidence on the risk at issue.

\subsection{Other Substantive Provisions}

In addition to the basic substantive provisions discussed in the previous section, the SPS Agreement also contains a number of other substantive provisions which deserve to be

\footnotetext{
173 Ibid., para. 124.
} 
mentioned. This section briefly examines the substantive provisions of the SPS Agreement relating to:

- equivalence;

- adaptation to regional conditions;

- control, inspection and approval procedures; and

- transparency and notification.

\subsubsection{Equivalence}

Due to differences between Members with regard to local climatic and geographical conditions, consumer preferences and technical and financial resources, it may sometimes be difficult or even undesirable to harmonise SPS measures. In such cases, the resulting variety of SPS measures can substantially hinder trade. However, the negative impact of divergent measures can be limited by the recognition that it is possible for different measures to achieve the same level of protection (i.e., be equally effective in reducing risk) and consequently allow imports of products that comply with different, but equally effective, SPS measures. For this reason, Article 4 of the SPS Agreement sets out certain obligations for Members with regard to the recognition of equivalence.

Article 4.1 of the SPS Agreement obliges Members to accept different SPS measures as equivalent if the exporting Member objectively demonstrates to the importing Member that its measures achieve the latter's appropriate level of protection. For this purpose, the importing Member must, upon request, be given reasonable access to carry out inspections, tests and other relevant procedures. In addition, Article 4.2 obliges Members to enter into consultations, upon request, with the aim of concluding agreements on the recognition of equivalence.

Problems with the implementation of Article 4 led the SPS Committee to engage in discussions on equivalence. These discussions resulted in the adoption, in October 2001, of the Equivalence Decision. ${ }^{174}$ This decision sets out binding guidelines for any Member requesting the recognition of equivalence and for the importing Member to whom such request is addressed. The decision also formally encourages the Codex Alimentarius

${ }^{174}$ Committee on Sanitary and Phytosanitary Measures, Decision on the Implementation of Article 4 of the Agreement on the Application of Sanitary and Phytosanitary Measures, G/SPS/19, dated 24 October 2001. 
Commission to complete its work on equivalence measures, as well as encouraging the OIE, and the Interim Commission on Phytosanitary Measures to elaborate guidelines. ${ }^{175}$

The International Committee of the OIE has since adopted the Guidelines for Reaching a Judgment on Equivalence of Sanitary Measures. ${ }^{176}$ The Interim Commission on Phytosanitary Measures of the IPPC agreed to include, as priorities in its work programme, work on the equivalence and efficacy of measures, which is considered a pre-requisite to an international standard for phytosanitary measure on equivalence. ${ }^{177}$ Such work is currently underway and remains a standing agenda item. ${ }^{178}$

The SPS Committee completed the work programme on equivalence in March 2004. However, it agreed to keep equivalence as a standing item on the agenda of its meetings. A second, revised, version of the Equivalence Decision was adopted in 2004, providing, in footnote, updated information on the actions that have been undertaken pursuant to the Decision. $^{179}$

The SPS Committee's Equivalence Decision and the clarifications thereto adopted through the work programme have gone some way towards illuminating and operationalizing the provision on equivalence. It now remains to be seen whether this work will bear fruit by promoting the recognition of equivalence in practice.

\subsubsection{Adaptation to regional conditions}

Although traditionally an importing country applies its SPS measures to an exporting country as a whole, differences in sanitary and phytosanitary conditions within exporting countries often exist. In particular, pest and disease prevalence is independent of national boundaries and can differ within a specific country, due to variations in climate, environment, geographic conditions and regulatory systems in place to control or eradicate pests or

\footnotetext{
175 Id., para. 10.

176 These guidelines were adopted at the $71^{\text {st }}$ General Session of the OIE, which took place in Paris, France, on May 18-23, 2003.

177 This occurred at the $5^{\text {th }}$ Session of the Interim Commission on Phytosanitary Measures, held in Rome, Italy, on April 7-11, 2003.

${ }^{178}$ As stated in the Report on the Activities of the Sanitary and Phytosanitary and Other Relevant WTO Activities in 2004 produced during the $7^{\text {th }}$ Session of the Interim Commission on Phytosanitary Measures, held in Rome, Italy, on April 4-8, 2005. ICPM 2005/INF/8.

179 Committee on Sanitary and Phytosanitary Measures, Decision on the Implementation of Article 4 of the Agreement on the Application of Sanitary and Phytosanitary Measures, Revision, G/SPS/19/Rev.2, July 23, 2004.
} 
diseases. The adaptation of SPS measures to the conditions prevailing in the region of origin of the product may thus be highly desirable. Failure of importing countries to recognize such inter-territory variations and appropriately adapt SPS measures to regional conditions is 'unfair' and leads to SPS measures that are excessively trade restrictive.

For this reason, Article 6 of the SPS Agreement obliges Members to ensure that their SPS measures are adapted to the SPS characteristics of the region of origin and destination of the product. These characteristics must be determined with reference to, inter alia:

- the level of pest or disease prevalence;

- the existence of eradication or control programs; and

- guidelines developed by international organisations.

Article 6.2 specifically obliges Members to recognise the concepts of pest-free and diseasefree areas and areas of low pest and disease prevalence. It is for the exporting Member to provide the necessary evidence that regions in its territory are pest- or disease-free or have low pest or disease prevalence. For this purpose, the importing Member is entitled to reasonable access to carry out inspection, testing and other relevant procedures.

Several Members, particularly developing countries, have raised concerns that the full benefits of regionalization, as provided for in Article 6, are not being realized due to difficulties implementing this provision. These Members have emphasized the importance of regionalization in reducing barriers to trade. As a result, the SPS Committee is currently conducting work in this area. Informal meetings held by the SPS Committee were dedicated to the regionalization issue, where the submissions of Members were discussed, ${ }^{180}$ and representatives of the OIE and IPPC made presentations. ${ }^{181}$ At these meetings, Members stressed the crucial role of the international organizations in creating specific standards in this area to facilitate the recognition of pest- and disease-free areas and areas of low pest and disease prevalence. Chile submitted in 2003 a proposal regarding the adoption of procedural

180 Committee on Sanitary and Phytosanitary Measures, Summary of the Meeting Held on 17-18 March 2004, Note by the Secretariat, G/SPS/R/33, May 7, 2004, para. 115.

${ }^{181}$ The OIE representative indicated that in May, 2004 that the OIE would consider for adoption simplified definitions and procedures for regionalization, which would provide Members with recommendations on regionalization for a broad range of diseases of terrestrial animals. This was realized at the $73^{\text {rd }}$ General Session of the OIE in May 2005, where member countries of the OIE adopted a revised chapter of the Terrestrial Animal Health Code on zoning and compartmentalization. This includes procedures for implementing zoning and compartmentalization, which take into account issues raised by Members in the SPS Committee. The IPPC representative described the ongoing efforts to develop standards related to the designation of pest-free areas and areas of low pest prevalence. The relevant existing standards are ISPM 4 (containing detailed requirements for the establishment of pest-free areas); ISPM 10 (containing information on pest-free areas of production); and at the seventh Interim Commission on Phytosanitary Measures (ICPM) in April 2005, agreement was reached to urgently develop a concept standard on "Guidelines for the recognition of the establishment of pest free areas and areas of low pest prevalence". However, there is as yet no IPPC procedure for officially recognizing pest-free areas. See Committee on Sanitary and Phytosanitary Measures, Summary of the Meeting Held on 17-18 March 2004, Note by the Secretariat, G/SPS/R/33, May 7, 2004, paras. 109-110. 
guidelines for the implementation of regionalization measures by the SPS Committee ${ }^{182}$; in 2005, it submitted a revised version of this proposal. ${ }^{183}$ Australia additionally submitted a proposal to address regionalization in $2005^{184}$. Each of the proposals reflect the common suggestion that the Committee address the regionalization issue in a similar way to the work it has done on equivalence and transparency.

In July of 2005, the SPS Committee included in the Review Of The Operation And Implementation Of The Agreement On The Application Of Sanitary And Phytosanitary Measures several recommendations regarding regionalization, most notably that it remain a standing issue and that a proposal be developed regarding implementation of Article VI using the Members' submitted proposals and experiences as a starting point. ${ }^{185}$

\subsection{3. $\quad$ Control, inspection and approval procedures}

In order to ensure that their SPS requirements are complied with, countries usually have control, inspection and approval procedures in place. If these procedures are complex, lengthy or costly, they may effectively restrict market access. To avoid this, Article 8 of the SPS Agreement obliges Members to comply with the disciplines contained in Annex $\mathrm{C}$ as well as other provisions of the SPS Agreement in the operation of their control, inspection and approval procedures. The disciplines in Annex $\mathrm{C}$ aim to ensure that procedures are not more lengthy and burdensome than is reasonable and necessary and do not discriminate against imports.

\subsubsection{Transparency and notification}

Lack of transparency with regard to SPS measures may constitute a barrier to market access since it increases the cost and difficulty for exporters in determining what requirements their

\footnotetext{
${ }^{182}$ Committee on Sanitary and Phytosanitary Measures, Draft Decision on the Implementation of Article 6 of the Agreement on the Application of Sanitary and Phytosanitary Measures, Proposal by Chile, Revision, G/SPS/W/140/Rev.1, October 30, 2003. Support for this proposal is evidenced by submissions made by Mexico, Argentina, Chile and Peru (G/SPS/GEN/388, G/SPS/GEN/440, G/SPS/GEN/417, G/SPS/GEN/418, G/SPS/GEN/445, G/SPS/W/129, G/SPS/W/140, G/SPS/GEN/381, G/SPS/GEN/433), followed later by other Members.

${ }^{183}$ Committee on Sanitary and Phytosanitary Measures. Monitoring of International Harm: Regionalization, Proposal by Australia. G/SPS/W/172, 4 March, 2005.

${ }^{184}$ Committee On Sanitary And Phytosanitary Measures. Proposal By Chile To Further The Discussions Concerning The Implementation Of Article 6 On Regionalization. G/SPS/W/171, 23 February 2005.

${ }^{185}$ Committee on Sanitary and Phytosanitary Measures. Review Of The Operation And Implementation Of The Agreement On The Application Of Sanitary And Phytosanitary Measures. G/SPS/36P, 11 July 2005, paras. 75-82.
} 
products must comply with on their export markets. This issue is addressed in Article 7 of the SPS Agreement, which obliges Members to notify interested Members of changes in their SPS measures and to provide information on their SPS measures according to Annex B of the SPS Agreement. Annex B contains detailed rules ensuring publication of adopted SPS measures and prior notification of proposed SPS measures that differ from international standards, to allow time for comments from other Members. It also obliges Members to create the necessary infrastructure to carry out their transparency obligations through the establishment of a national Notification Authority and Enquiry Point.

In June, 2003, the SPS Committee held a meeting regarding difficulties Members have encountered concerning the operation of Enquiry Points. Prior to the meeting, a questionnaire was circulated by the Secretariat on the operation of Enquiry Points and National Notification Authorities, to which eighty responses were received. At the meeting, officials from Members' Enquiry Points and National Notification Authorities came together for indepth discussions focusing on the problems encountered with the operation of these bodies and the identification of possible solutions. ${ }^{186}$ The Secretariat will use the information gathered to identify best practice models to help developing countries operate their Enquiry Points effectively. As of May 2005, 139 of 148 Members have identified their Enquiry Point (94\%) and 130 Members (87\%) have designated a National Notification Authority. ${ }^{187}$

Article 5.8 also contains an important obligation to the promotion of transparency. It obliges Members to provide information, upon request, regarding the reasons for their SPS measures where such measures are not 'based on' international standards or no relevant international standards exist. A Member, who has reason to believe that such an SPS measure does or could potentially restrain its exports, may request information under Article 5.8.

In Japan-Apples, the issue arose whether certain changes in Japan's measure "may have a significant effect on trade of other Members" and whether such Members should thus have been notified. The Panel referred to the guidelines on this concept adopted by the SPS Committee and held that:

...[T]he most important factor in this regard is whether the change affects the conditions for market access for the product concerned, that is, would the exported product (apple fruit from the United States in this case) still

186 Committee on Sanitary and Phytosanitary Measures, Special Meeting of the SPS Committee on the Operation of Enquiry Points held on 31 October 2003, G/SPS/R/32, February 6, 2004.

187 Committee on Sanitary and Phytosanitary Measures, Review Of The Operation And Implementation Of The Agreement On The Application Of Sanitary And Phytosanitary Measures. G/SPS/36, para. 27, 11 July 2005. 
be permitted to enter Japan if they complied with the prescription contained in the previous regulations. If this is not the case, then we must consider whether the change could be considered to potentially have a significant effect on trade of other Members. In this regard it would be relevant to consider whether the change has resulted in any increase in production, packaging and sales costs, such as more onerous treatment requirements or more time-consuming administrative formalities. ${ }^{188}$

The crux of the issue is therefore whether the changes have an actual or potential effect on the conditions for market access. If so, Members must be notified of the changes.

To assist Members comply with the obligations of Article 7, the SPS Committee has created a handbook How to Apply the Transparency Provisions of the SPS Agreement. ${ }^{189}$ The committee also provided Members with model procedures for notifying other members of changes in SPS measures, including guidelines on timeliness of notification, procedures for requesting and providing information, and sample notification forms. ${ }^{190}$

The issue of notification guidelines to increase transparency relating to special and differential treatment was recently addressed by the SPS committee. Egypt originally raised the issue by proposing the inclusion of a box on special and differential treatment in the notification formats, where Members should indicate ex ante what special treatment they are providing to affected developing countries. ${ }^{191}$ Building upon this, Canada put forth a proposal to oblige Members, ex post, to notify Members of requests for special and differential treatment arising from their published measures, indicating whether such treatment has been provided and giving reasons in case of a refusal to do so. ${ }^{192}$ After adopting Canada's proposal in principle in April 2003 the Committee continued to debate the specific implementation due to objections by Malaysia that the proposal placed the onus on the developing country to raise its concerns regarding the notified measure. However, the proposal was adopted at the October 2004 SPS Committee meeting, including the duty of developing country Members to identify concerns or difficulties with measures to be adopted and contact the relevant Member to request technical assistance to meet the measures requirements or differential treatment. When solutions are agreed upon, the Member that

188 Panel Report, Japan-Apples. Para. 8.314. After comparing the two existing measures (which predated the SPS Agreement) with the two new measures, the Panel did not consider that the changes in one measure could have a significant effect on the trade of other Members, and was unable to determine if the changes to the second measure were strictly editorial or introduced substantial changes. It therefore found that the US had failed to make a prima facie case of violation of Article 7 of the SPS Agreement.

189 The World Trade Organization. How to Apply the Transparency Provisions of the SPS Agreement. September 2002. PDF version available at: http://www.wto.org/english/tratop_e/sps_e/sps_e.htm, visited 10 October 2005.

190 Committee on Sanitary and Phytosanitary Measures. Recommended Procedures for Implementing the Transparency Obligations of the SPS Agreement. G/SPS/7/Rev.2, 2 April 2002.

191 This proposal (G/SPS/GEN/358) was supported by many developing countries, who believed it would encourage developed countries to build into their measures leniency for developing countries, such as longer compliance periods. Developed countries (e.g. EC, Canada, U.S.) questioned whether this would be effective in ensuring special and differential treatment.

${ }^{192}$ Committee on Sanitary and Phytosanitary Measures. Enhancing Transparency Of Special And Differential (S\&D) Treatment Within The SPS Agreement. G/SPS/W/127, 30 October 2005. 
enacted the measure must submit an addendum to its original notification to the WTO Secretariat. ${ }^{193}$

It is interesting to note that the Secretariat is obliged, under paragraph 9 of Annex B, to draw the attention of developing country Members to any notifications relating to products of particular interest to them. As it is difficult for the Secretariat to establish which notifications affect products significant to developing countries, it fulfils this obligation by circulating, to all Members, monthly lists of notifications. ${ }^{194}$

Further, in order to address the problems Members face in translating proposed regulations of other Members into a language in which they can work, the Secretariat has recently established a mechanism to circulate information on the availability of unofficial translations of draft regulations notified by Members. ${ }^{195}$

\subsection{Institutional and Procedural Provisions of the SPS Agreement}

In addition to the substantive provisions discussed above, the SPS Agreement also contains a number of institutional and procedural provisions. This section deals with the provisions on:

- the SPS Committee; and

- dispute settlement.

\subsection{1.}

\section{SPS Committee}

The Committee on Sanitary and Phytosanitary Measures, commonly referred to as the 'SPS Committee', is established under Article 12.1 of the SPS Agreement with a mandate to carry out the functions necessary for the implementation of the SPS Agreement and the furtherance of its objectives. ${ }^{196}$ The SPS Committee is composed of representatives of all WTO Members and takes decisions by consensus. It usually meets three times a year.

\footnotetext{
${ }^{193}$ Committee on Sanitary and Phytosanitary Measures. Procedure To Enhance Transparency Of Special And Differential Treatment In Favour Of Developing Country Members, G/SPS/33, 2 November 2005.

${ }^{194}$ This number includes the 25 Member States of the European Union, together with the European Communities, in respect of which a single Notification Authority, the European Commission Directorate General for Health and Consumer Protection, is responsible for notifications. Separate Enquiry Points have been notified for the European Communities and each of its Member States. See Committee on Sanitary and Phytosanitary Measures, Implementation of the Transparency Obligations as of 18 June 2004 , Note by the Secretariat, Revision, G/SPS/GEN/27/Rev.13, June 21, 2004.

${ }^{195}$ Committee on Sanitary and Phytosanitary Measures, Unofficial Translation, Note by the Secretariat, G/SPS/GEN/487, April 23, 2004.

196 In terms of this mandate, the SPS Committee has, for example, adopted the Equivalence Decision referred to above, Sec. 3.5.1.
} 
The SPS Committee has three main tasks. First, it is a forum for consultations and must encourage and facilitate, under Article 12.2, consultations or negotiations between Members on SPS issues. Often SPS disputes can be resolved through such consultations without resort to dispute settlement. Second, according to Article 12.2 the SPS Committee must encourage the use of international standards by Members. In this respect, the SPS Committee is obliged, by Article 12.3, to maintain close contact with the international standard-setting organisations, and must develop a procedure for the monitoring of the process of international harmonisation in terms of Article 12.4. ${ }^{197}$ Article 12.6 allows the SPS Committee to invite the standard-setting organisations to examine specific issues relating to a particular standard, including the reasons for non-use. Third, the SPS Committee is obliged, by Article 12.7, to undertake a review of the operation and implementation of the SPS Agreement three years after its entry into force and as necessary thereafter. Where appropriate, it may propose amendments to the SPS Agreement to the Council for Trade in Goods. The first review was completed in 1999 and no amendments were proposed. In the Decision on Implementation-Related Issues and Concerns, adopted by the Doha Session of the Ministerial Conference, the SPS Committee is instructed to conduct subsequent reviews at least once every four years. ${ }^{198}$

As a result of this decision, the WTO Secretariat has determined that the report of the next review should be prepared for the Sixth Session of the Ministerial Conference. The Secretariat also proposed, in consultation with the Chairman of the SPS Committee, a procedure for the review process. This procedure consists of a series of informal meetings, conducted back-to-back with the regular SPS Committee meetings, where issues identified by Members will be discussed. Members will be invited to submit papers in advance of the meetings and the Chairman will report on the results of the meetings during the regular SPS Committee meeting. ${ }^{199}$

\subsubsection{Dispute settlement}

The provisions of Articles XXII and XXIII of the GATT 1994, as elaborated by the DSU, ${ }^{200}$ apply to consultations and the settlement of disputes under the SPS Agreement, except as

197 Such a procedure was developed in 1997 (see G/SPS/11), in terms of which the SPS Committee draws up annual reports regarding the use of existing standards, the need for new standards and work on the adoption of such standards.

198 Ministerial Conference, Implementation-Related Issues and Concerns WT/MIN(01)/17, dated 14 November 2001.

${ }^{199}$ Committee on Sanitary and Phytosanitary Measures, Proposed Process for the Review of the Operation and Implementation of the Agreement, Note by the Secretariat, G/SPS/W/147, June 10, 2004.

${ }^{200}$ For a detailed discussion of the WTO dispute settlement system, see P. Van den Bossche, The Law and Policy of the World Trade Organization Chapter 3: WTO Dispute Settlement (Cambridge University Press) (2005). 
otherwise provided. ${ }^{201}$ The SPS Agreement contains only one 'special or additional rule and procedure'. ${ }^{202}$ Article 11.2 of the SPS Agreement authorises panels to consult experts to help them to deal with the complex issues of scientific fact that arise in SPS disputes. ${ }^{203}$ These experts are chosen by the panel in consultation with the parties. Panels may also organize advisory technical expert groups or consult relevant international organisations. They may do so at the request of either party to the dispute or on their own initiative. In all SPS disputes to date, panels have consulted individual experts to help them to understand the complex issues of scientific fact that arose in these disputes. ${ }^{204}$

Panels may use the information provided by experts to inform their understanding of all issues presented in a case. The Appellate Body confirmed this position in Japan-Apples, where it rejected Japan's claim that the Panel had exceeded the bounds of its investigative authority by issuing a finding regarding the transmission of fire blight regarding apples other than mature, symptomless apples, as the evidence submitted by the US was constrained to such apples. ${ }^{205}$ The Appellate Body stated that the Panel had acted within the limits of its investigative authority, as "it did nothing more than assess the relevant allegations of fact asserted by Japan, in the light of the evidence submitted by the parties and the opinions of the experts." ${ }^{206}$ It thus clarified that a panel may use the evidence of its experts to assist it in assessing not only the claims of the complaining Member, but also the allegations of the responding Member. In doing so, it cannot be said to be exceeding its authority under Article 11.2.

It is important to note, however, that this is the limit of the experts' role; the evidence of the experts cannot be used to make a case for one of the parties.

The issue of burden of proof often arises in disputes regarding the appropriateness of SPS measures. The Appellate Body clarified the requirements concerning this burden in JapanApples. In that case, the US argued that there was insufficient scientific evidence, for purposes of Article 2.2, that mature, symptomless apples could form a transmission pathway for fire blight. To counter these arguments, Japan averred that, due to failures in export

\footnotetext{
201 Article 11 of the SPS Agreement.

202 See Appendix 2 of the DSU. Note that special or additional dispute settlement rules and procedures prevail over the rules and procedures of the DSU to the extent that they differ. (see Article 1.2 of the DSU).

203 Note that Article 13 of the DSU generally authorises panels to seek information and technical advice from any individual or body, and to seek information from any source, consult experts or request advisory reports. This provision also applies to disputes under the SPS Agreement.

204 See EC-Hormones, Australia - Salmon, Japan-Agricultural Products II and Japan - Apples.

205 Id., para. 158.

206 Id.
} 
control systems, infected or immature apples may also be exported and that these apples could serve as a pathway for fire blight. The US limited its arguments to the issue of mature, symptomless apples. On the basis of the scientific evidence presented to it, the Panel agreed with the US that Japan's measure, as it applied to mature, symptomless apples, was maintained without sufficient scientific evidence and concluded that it had not been established with sufficient scientific evidence that infected or immature apples could serve as a pathway for the transmission of fire blight. ${ }^{207}$ On appeal, Japan argued that the Panel had erred in shifting the burden of proof to Japan in respect of infected or immature apples before the US had made a prima facie case in that regard. The Appellate Body rejected Japan's contention, holding:

It is important to distinguish, on the one hand, the principle that the complainant must establish a prima facie case of inconsistency with a provision of a covered agreement from, on the other hand, the principle that the party that asserts a fact is responsible for providing proof thereof. In fact, the two principles are distinct. In the present case, the burden of demonstrating a prima facie case that Japan's measure is maintained without sufficient scientific evidence, rested on the United States. Japan sought to counter the case put forward by the United States by putting arguments in respect of apples other than mature, symptomless apples being exported to Japan as a result of errors of handling or illegal actions. It was thus for Japan to substantiate those allegations; it was not for the United States to provide proof of the facts asserted by Japan. Thus, we disagree with Japan's assertion that "the shift of the burden of proof to Japan was made prematurely before the demonstration of a prima facie case by the United States." There was no "shift of the burden of proof " with respect to allegations of fact relating to apples other than mature, symptomless apples, for Japan was solely responsible for providing proof of the facts it had asserted. Moreover, it was only after the United States had established a prima facie case that Japan's measure is maintained without sufficient scientific evidence, that the Panel had to turn to Japan's attempts to counter that case. ${ }^{208}$

This finding is useful in clarifying the issue of the burden of proof in cases where there are several hypotheses regarding the perceived risks underlying an SPS measure. It is not necessary for the complainant to address all possible hypotheses and establish that there is insufficient evidence of risk for each. ${ }^{209}$ According to the Appellate Body in this case, the Panel evidently found it sufficient for the US to address whether mature symptomless apples could serve as a transmission pathway for fire blight. It noted, referring to its previous finding in US-Wool Shirts and Blouses that "the nature and scope of evidence required to establish a prima facie case 'will necessarily vary from measure to measure, provision to

\footnotetext{
${ }^{207}$ This was due to the fact that Japan did not present sufficient scientific evidence that the last stage of the transmission pathway of fire blight from the infected imported apple to the host plant, was likely to be completed. Panel Report, Japan- Apples, para. 8.168.

208 Report of the Appellate Body, Japan - Apples, para. 157.

209 This was argued by Japan but rejected by the Appellate Body. Id., para. 159.
} 
provision, and case to case.",210 In sum, once a prima facie case is established, the respondent will bear the burden of proving the allegations it makes to refute the complainant's case.

The standard of review regarding SPS measures was also questioned by Japan in the JapanApples case. Japan argued, on appeal, that the Panel had failed to adequately take into account the precautionary principle in its evaluation of the evidence. The panel experts in this case had recognized the need for caution with respect to the elimination of the phytosanitary measures protecting Japan from fire blight. According to Japan, this fact should have been given greater weight by the Panel in considering the evidence regarding the completion of the transmission pathway for fire blight. ${ }^{211}$ The Appellate Body noted that Japan did not argue that the precautionary principle should have been applied as distinct from the provisions of the SPS Agreement, nor did it argue that the Panel should have used the precautionary principle as part of its interpretative analysis of the Agreement. Instead, it understood Japan to argue that the principle was embodied in the cautionary opinions of the experts and should have been given greater weight in the Panel's conclusions on the completion of the pathway. The Appellate Body noted that it is established case law that the credibility and weight to be properly ascribed to a particular piece of evidence is in the discretion of a panel as the trier of facts. ${ }^{212}$ This discretion is limited only by a panel's duty to make an "objective assessment" of the facts. Since Japan made no argument challenging the objectivity of the Panel's assessment, it failed to establish a violation of Article $11 .^{213}$

This finding of the Panel reinforces the conclusion that the possible relevance of the precautionary principle for purposes of the SPS Agreement is limited to the particular formulation it has been given in Article 5.7. Outside this article, the precautionary principle plays no role, according to the case law, in guiding the interpretation of the SPS Agreement or the evaluation of the evidence. It also emphasizes that the standard of review to be applied by panels remains an "objective assessment" of the matter, even in cases of scientific uncertainty.

\footnotetext{
210 Appellate Body Report, Japan-Apples, para. 160. In footnote, the Appellate Body referred to the Appellate Body Report, p. 14, DSR 1997:I, 323, at 335.

211 This evidence was considered for purposes of the Panel's finding under Article 2.2 of the SPS Agreement.

212 See, e.g., Appellate Body Report, US - Wheat Gluten, para. 151.

213 Appellate Body Report, Japan- Apples, para. 283.
} 
To date (August 2005), there have been thirty formal complaints under the SPS Agreement regarding twenty-six separate issues, three of which only involved minor SPS issues. No African country or least-developed country (LDC) has initiated a complaint under the SPS Agreement. Consultations are officially still pending in fifteen cases. A mutually agreed upon solution has been reported in six cases. ${ }^{214}$ Eight disputes, ${ }^{215}$ regarding five separate issues, have proceeded to adjudication by a panel under the SPS Agreement ${ }^{216}$ and five panel reports have thus far been issued. ${ }^{217}$ All of these have been appealed, resulting in five Appellate Body reports. ${ }^{218}$ One dispute is currently still before a panel. ${ }^{219}$ Developing countries ${ }^{220}$ have been involved in thirteen disputes, in nine cases as complainant ${ }^{221}$ and in nine as defendant. $^{222}$ In only one of these disputes involving developing countries, namely $E C$ Biotech Products, has the dispute proceeded to adjudication. ${ }^{223}$

214 Korea-Measures Concerning the Shelf-Life of Products (Complaint by the United States), WT/DS5; Korea-Measures Concerning Bottled Water (Complaint by Canada), WT/DS20; Australia-Measures Affecting the Importation of Salmonids (Complaint by the United States), WT/DS21; India-Quantitative Restrictions on Imports of Agricultural, Textile and Industrial Products (Complaint by the European Communities), WT/DS96; Turkey-Certain Import Procedures for Fresh Fruit (Complaint by Ecuador), WT/DS237; and Mexico-Certain Measures Preventing the Importation of Black Beans from Nicaragua (Complaint by Nicaragua), WT/DS284.

${ }^{215}$ These eight disputes are the separate complaints by the United States and Canada in EC-Hormones (WT/DS48, WT/DS26) that were heard by separate panels, composed of the same panelists, which issued separate but largely identical reports; the complaint by the United States in Japan-Agricultural Products II (WT/DS76); the complaint by Canada in Australia-Salmon (WT/DS18); the complaint by the United States in Japan-Apples, (WT/DS245), and the separate complaints by the United States, Canada and Argentina in EC-Biotech (WT/DS291, WT/DS292, WT/DS293) which is being heard by a single panel. This count does not include the compliance disputes under Article 21.5 DSU in Australia-Salmon (WT/DS18), Japan-Apples (WT/DS245), and ECHormones (WT/DS321, WT/DS322).

216 The dispute EC-Asbestos (WT/DS135) also proceeded to adjudication by a panel and the Appellate Body, but the claims under the SPS Agreement were not pursued in the adjudication process.

217 See the WTO Panel Reports in EC-Hormones, Australia-Salmon, Japan-Agricultural Products, and Japan-Apples. The findings in these cases have been discussed in previous sections where relevant.

218 See the Appellate Body Reports in EC - Hormones, Australia - Salmon, Japan - Agricultural Products, and Japan - Apples. The findings in these cases have been discussed in previous sections where relevant.

219 A panel was established on to address the complaints of the US, Argentina and Canada against the EC's measure with regard to the products of biotechnology (WT/DS291, 292 and 293).

220 Developing countries here is interpreted broadly to include economies in transition.

221 Croatia-Measure Affecting Imports of Live Animals and Meat Products (Complaint by Hungary), WT/DS297; European Communities-Measures Affecting the Approval and Marketing of Biotech Products (Complaint by Argentina), WT/DS293; MexicoCertain Measures Preventing the Importation of Black Beans from Nicaragua (Complaint by Nicaragua), WT/DS284; AustraliaCertain Measures Affecting the Importation of Fresh Pineapple (Complaint by the Philippines), WT/DS271; Australia-Certain Measures Affecting the Importation of Fresh Fruit and Vegetables (Complaint by the Philippines), WT/DS270; Turkey-Import Ban on Pet Food from Hungary (Complaint by Hungary), WT/DS256; Turkey-Certain Import Procedures for Fresh Fruit (Complaint by Ecuador), WT/DS237; Egypt-Import Prohibition on Canned Tuna with Soybean Oil (Complaint by Thailand), WT/DS205; and EC-Restrictions on Certain Import Duties on Rice (Complaint by India), WT/DS134.

222 Croatia-Measures Affecting Imports of Live Animals and Meat Products (Complaint by Hungary), WT/DS297; Mexico-Certain Measures Preventing the Importation of Black Beans from Nicaragua (Complaint by Nicaragua), WT/DS284; India-Import Restrictions Maintained Under the Export and Import Policy 2002-2007 (Complaint by the European Communities), WT/DS279; Turkey-Import Ban on Pet Food from Hungary (Complaint by Hungary), WT/DS256; Turkey-Certain Import Procedures for Fresh Fruit (Complaint by Ecuador), WT/DS237; Egypt-Import Prohibition on Canned Tuna with Soy Oil (Complaint by Thailand), WT/DS205; Mexico-Measures Affecting Trade in Live Swine (Complaint by the United States), WT/DS203, Slovak RepublicMeasures Concerning the Importation of Dairy Products and the Transit of Cattle (Complaint by Switzerland), WT/DS133; and India-Quantitative Restrictions on Imports of Agricultural, Textile and Industrial Imports (Complaint by the European Communities), WT/DS96.

223 In Australia-Certain Measures Affecting the Importation of Fresh Fruit and Vegetables (Complaint by the Philippines), WT/DS270, the Philippines requested the establishment of a panel once, on July 10, 2003. This panel request was blocked by Australia. The Philippines has not yet submitted its second panel request to the DSB (at which time the decision to establish a panel would be taken by reverse consensus in the DSB and could therefore not be blocked), and thus no panel has yet been established to hear this dispute. In Turkey-Certain Import Procedures for Fresh Fruit (Complaint by Ecuador), WT/DS237, a panel request was submitted by Ecuador on June 14, 2002, but a mutually agreed solution was subsequently reached. 


\subsection{Special Provisions for Developing Countries}

Although the disciplines contained in the SPS Agreement apply equally to developed and developing country Members, the SPS Agreement does reflect a recognition of the special constraints that developing countries face. For this reason, special rules exist to take account of developing country needs. This section examines the provisions of the SPS Agreement concerning:

- technical assistance; and

- $\quad$ special and differential treatment for developing country Members. ${ }^{224}$

\subsubsection{Technical assistance}

Due to the financial and human resource constraints encountered by developing countries, they are often in need of technical assistance in various areas of relevance to the SPS Agreement. Technical assistance encompasses not only information to enhance understanding of the disciplines of the SPS Agreement and practical training on its operation, but also the provision of soft infrastructure (training of technical and scientific personnel and the development of national regulatory frameworks) and hard infrastructure (laboratories, equipment, veterinary services and the establishment of pest- or disease-free areas). ${ }^{225}$

Technical assistance is dealt with in Article 9 of the SPS Agreement. In terms of Article 9.1, Members agree to facilitate the provision of technical assistance to other Members, especially developing countries, either bilaterally or through international organisations. Such technical assistance may take various forms and may aim, inter alia, at helping developing countries to comply with SPS measures on their export markets. Article 9.2 deals with the situation where a Member's SPS measure requires substantial investments from an exporting developing country Member and obliges the importing Member to consider providing technical assistance to allow the developing country to maintain or increase its market opportunities for the relevant product. These provisions are in the nature of 'bestendeavor' obligations and thus difficult to enforce. The Doha Decision on Implementation urges Members to provide technical and financial assistance to least developed country

\footnotetext{
224 Note that Article 14 of the SPS Agreement provided for the possibility for developing and least developed country Members to delay, until 1997 and 2000 respectively, the implementation of their obligations under the SPS Agreement.

225 This typology of technical assistance was drawn up by the Secretariat (see Committee on Sanitary and Phytosanitary Measures, Technical Assistance Typology: Note by the Secretariat, G/SPS/GEN/206, dated 18 October 2000.)
} 
Members to help them respond to SPS measures that may affect their trade and to assist them to implement the SPS Agreement. ${ }^{226}$

The results of this review were discussed within the Codex and recommendations were made to the Food and Agriculture Organization (FAO) and the World Health Organization (WHO) governing bodies regarding reforms to the Codex structure and decision-making process. Consequently several important changes to the CAC Rules of Procedure were considered at the twenty-seventh session of the CAC in 2004. Similarly, the IPPC established a trust fund for technical assistance in 2003, aimed at helping developing countries to participate in standard-setting activities and meetings and to implement resulting standards. ${ }^{227}$

At the SPS Committee meeting of March 17-18, 2004, the CAC representative reported that the contributions to the FAO/WHO Trust Fund have reached the threshold of US\$500,000 needed to operationalize it. However, as this amount is insufficient to significantly increase developing country participation in the work of the CAC, he encouraged further contributions. Actual and expected contributions through July 2005, in addition to 2004 contributions earmarked for 2005, equal a budget for that year of US $\$ 1,829,000 .{ }^{228}$ Between January and June of 2005, 150 delegates from 78 countries received funding to attend 12 Codex meetings. Sixty-one percent of these attendees were from Least Developed Countries. $^{229}$

\subsubsection{Special and differential treatment}

The SPS Agreement provides for special and differential treatment of developing countries, both by other Members and by the SPS Committee in order to take account of the difficulties they face in implementing the SPS Agreement and complying with SPS measures on their export markets. These provisions aim to give additional flexibility to developing countries.

Article 10.1 of the SPS Agreement obliges Members to take account of developing country (and especially least-developed country) needs in preparing and applying SPS measures. Article 10.2 encourages, but does not oblige Members to grant developing countries longer

\footnotetext{
226 Ministerial Conference, Implementation-Related Issues and Concerns, WT/MIN(01)/17, dated 14 November 2001, para. 3.6.

227 Committee on Sanitary and Phytosanitary Measures, Summary of the Meeting Held on 17-18 March 2004, Note by the Secretariat, G/SPS/R/33, May 7, 2004, para. 140.

${ }^{228}$ FAO/WHO Project and Fund For Enhanced Participation in Codex. Fifth Progress Report. para. 8. CAC/28INF/12. Session held 49 July 2005. Available at www.who.int/foodsafety/codex/prog5e.pdf, visited 10 October 2005.

229 Ibid., para 3.
} 
time-frames for compliance with new SPS measures where the appropriate level of protection allows. This extended period was specified as normally not less than six months by the Doha Decision on Implementation. The Decision on Implementation further provides that if longer time-frames for compliance are not possible and a Member identifies specific problems with the measure, the importing Member must enter into consultations with a view to reaching a mutually satisfactory solution that continues to achieve its appropriate level of protection. ${ }^{230}$

An obligation to allow a reasonable period between publication of a measure and its entry into force for exporting Members, especially developing countries, to adapt to the new measure, is contained in paragraph 2 of Annex B. An exception is made for urgent circumstances. Once again, the Doha Decision on Implementation specifies this period as normally not less than six months, but notes that the particular circumstances of the measure and the actions needed for its implementation must be considered. ${ }^{231}$

In order to enable developing countries to comply with their obligations under the SPS Agreement, Article 10.3 allows the SPS Committee to grant them, upon request, specified, time-limited exemptions from some or all of their obligations, taking account of their financial, trade and development needs. To date no developing country has requested such an exemption.

Lastly, Article 10.4 provides that Members should encourage and facilitate the participation of developing countries in the relevant international organisations. This provision does not contain any binding obligation but is purely hortatory.

\section{CONCLUSION}

In modern society, products are often subject to requirements relating to their characteristics and/or the manner in which they are produced. The purpose of these requirements may be the protection of life or health, the protection of the environment, the prevention of deceptive practices or to ensure the quality of products. These requirements may constitute formidable barriers to trade. Moreover, procedures set up to verify whether a product meets certain requirements may obstruct trade.

\footnotetext{
230 Ministerial Conference, Implementation-Related Issues and Concerns, WT/MIN(01)/17, dated 14 November 2001, para. 3.1

231 Ibid., para. 3.2
} 
These barriers to trade are referred to as technical barriers to trade. One must distinguish between:

- the general category of technical barriers to trade, for which rules have been set out in the TBT Agreement; and

- a special category of technical barriers to trade, namely sanitary and phytosanitary measures, for which rules are provided in the SPS Agreement.

The rules of the TBT Agreement and the SPS Agreement are of great importance to international trade. They go significantly beyond the GATT obligations not to discriminate among or against imported products or not to impose quantitative restrictions but also impose certain international disciplines on national regulation regarding products, their characteristics and production.

The rules of the TBT Agreement apply to technical regulations, standards and conformity assessment procedures relating to:

- products (both industrial and agricultural); and

- $\quad$ related processes and production methods (PPMs).

A measure is a 'technical regulation' within the meaning of the TBT Agreement if:

- the measure applies to an identifiable product or group of products;

- the measure lays down product characteristics; and

- compliance with the product characteristics laid down in the measure is mandatory.

A standard differs from a technical requirement in that the compliance with a standard is not mandatory.

Although the TBT Agreement is mainly addressed to central government bodies, it extends its application also to local government bodies and non-governmental bodies by imposing on WTO Members the obligation:

- to take measures in order to ensure compliance with the TBT Agreement by local government bodies and non-governmental bodies; or

- to refrain from taking measures that could encourage actions by these other bodies that are inconsistent with the provisions of the TBT Agreement.

With regard to the relationship between the TBT Agreement and other WTO agreements, note that the applicability of the SPS Agreement or the Agreement on Government Procurement to a specific measure excludes the applicability of the TBT Agreement to that measure. 
However, the TBT Agreement and the GATT 1994 can both be applicable to a specific measure.

The TBT Agreement requires that, in respect of TBT measures, Members accord national treatment and MFN treatment to products imported from other Members. The TBT Agreement also requires that TBT measures do not create unnecessary obstacles to international trade. To this end, technical regulations, for example, shall not be more trade restrictive than necessary to fulfil legitimate objectives, such as the protection of human life or health or the protection of the environment. The TBT Agreement requires that Members base their technical regulations on international standards, except when these standards would be an ineffective or inappropriate means of fulfilling the legitimate objectives pursued. Furthermore, the TBT Agreement requires WTO Members to consider accepting, as equivalent, the technical regulations of other Members if they are satisfied that the foreign technical regulations adequately fulfill the legitimate objectives pursued by their own technical regulations. The TBT Agreement subjects Members to a number of detailed transparency and notification obligations.

Members consult, regarding any matters pertaining to the operation or objectives of the $T B T$ Agreement, in the TBT Committee which is composed of all WTO Members and meets several times a year. The WTO dispute settlement rules and procedures apply to disputes concerning the TBT Agreement. The TBT Agreement contains a few special or additional rules and procedures, primarily with regard to the possibility for panels for consulting technical experts. Finally, in recognition of the difficulties developing country Members may face in implementing the obligations under the TBT Agreement, the TBT Agreement provides for technical assistance and some special and differential treatment for developing country Members.

The SPS Agreement applies to SPS measures that may affect international trade. Whether a measure is an 'SPS measure', depends on its purpose or aim. In broad terms, an 'SPS measure' is a measure that:

- aims at the protection of human or animal life or health from food-borne risks; or

- aims at the protection of human, animal or plant life or health from risks from pests or diseases. 
The adoption and implementation of SPS measures is sometimes in the hands of bodies other than central government, such as regulatory agencies, regional bodies and sub-federal governments. The SPS Agreement takes this into account by providing that Members are fully responsible for the implementation of the Agreement and must enact and implement positive measures to ensure the observance of its rules by entities other than central government bodies.

With regard to the relationship between the SPS Agreement and other WTO agreements, note that when a measure is an 'SPS measure' as defined in Annex A of the SPS Agreement, the SPS Agreement applies to the exclusion of the TBT Agreement. However, no relationship of mutual exclusivity exists between the SPS Agreement and the GATT 1994.

The SPS Agreement explicitly acknowledges the sovereign right of WTO Members to take SPS measures. At the same time, however, the SPS Agreement subjects Members to a number of obligations regarding their SPS measures. These obligations include:

- the obligation to take or maintain only SPS measures necessary to protect human, animal or plant life or health;

- the obligation to take or maintain only SPS measures 'based on' scientific principles and on sufficient scientific evidence;

- the obligation not to adopt or maintain SPS measures that arbitrarily or unjustifiably discriminate or constitute a disguised restriction on trade; and

- the obligation to base SPS measures, as much as possible and appropriate, on international standards.

The substantive obligations provided for in the SPS Agreement also include obligations with respect to risk analysis, i.e., risk assessment and risk management. With regard to risk assessment, the SPS Agreement primarily requires that SPS measures are 'based on' the relevant type of risk assessment. With regard to risk management, the SPS Agreement primarily requires that Members must:

- avoid arbitrary or unjustifiable distinctions in the levels of protection deemed appropriate in different situations, if these distinctions lead to discrimination or disguised restrictions on trade; and

- $\quad$ ensure that SPS measures are not more trade-restrictive than required to achieve their appropriate level of protection. 
Where scientific information is insufficient, the SPS Agreement allows Members to take, under certain conditions, provisional SPS measures which are not based on scientific evidence. The SPS Agreement thus incorporates the precautionary principle.

The SPS Agreement also provides for substantive provisions relating to the recognition of equivalence of SPS measures of other Members; relating to the obligation of Members to adapt their SPS measures to regional conditions; relating to control, inspection and approval procedures; and relating to transparency and notification obligations regarding SPS measures.

Members consult regarding any matters pertaining to the operation or objectives of the SPS Agreement in the SPS Committee. This Committee is composed of all WTO Members and meets several times a year. The WTO dispute settlement rules and procedures apply to disputes concerning the SPS Agreement. The SPS Agreement contains one special or additional dispute settlement rule, providing panels with the possibility to consult scientific experts. Finally, the SPS Agreement acknowledges the difficulties developing country Members may face in implementing the obligations under the SPS Agreement and thus provides for technical assistance and some special and differential treatment for developing country Members. 


\section{The Maastricht Faculty of Law Working Paper series:}

2005/6 Peter Van den Bossche, Denise Prévost \& Mariëlle Matthee, 'WTO Rules on Technical Barriers to Trade'

2005/5 John Hagedoorn and Geerte Hesen, 'The Governance of Inter-Firm Technology Partnerships and Contract Law - An Analysis of Different Modes of Partnering and their Contractual Setting'

2005/4 Michael Faure, 'Economic Criteria for Compulsory Insurance'

2005/3 Iveta Alexovičová \& Peter Van den Bossche, 'Effective Global Economic Governance by the World Trade Organization'

2005/2 Michael Faure \& Wang Hui, 'Economic Analysis of Compensation for Oil Pollution Damage'

2005/1 Peter Van den Bossche, 'From Afterthought to Centerpiece: The WTO Appellate Body and its Rise to Prominence in the World Trading System'

All papers are available for download at http://www.rechten.unimaas.nl/maastrichtworkingpapers 